HNF-SP-1105, Rev. 6

\title{
Hanford Fire Department FY 1999 Annual Work Plan WBS 6.5.7
}

DynCorp Tri-Cities Services, Inc.

\author{
August 1998
}

Prepared for the U.S. Department of Energy

Assistant Secretary for Environmental Management

Projed Hanford Management Contractor for the

U.S. Department of Energy under Contract DE-ACO6-96RL13200

Approved for public release; distribution is unlimited 
LBGAL DSCLARIER

This report was prepured as an wocoun of watk panearod by an socncy of the United Strea Goverimen. Noither the Unitod Sines Government nor any agency thereof, nor any of their employees, nox any of their contrectors

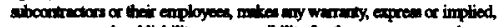

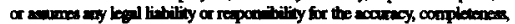

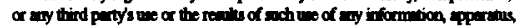

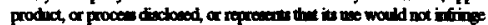
privedy owned righ Reforence herein to any pecific onmmercial product, procen, of service by trade neme, tredemed, menfincture, or otherwise, does

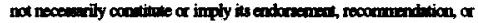

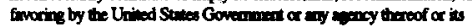

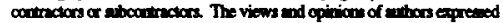

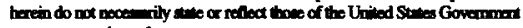

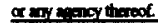

This repont has been reproduced from the bes available copy. Arilible in peper copy and microfiche.

Avilbule to the US. Department of Energy

and ins contractoss fiom

U.S. Depertment of Enargy

Ofice of Sciectific and Technical Informmion (OSTI)

P.O. Box 62

Oet Ridga TN 37831

(615) $576-8401$

Availeble to the public from the U.S. Depment of Commerce

Natioul Techrical Inform tion Service (NITS)

5285 Part Royal Roed

Springfield. VA 22161

(703) $487-4650$

Pitued of the Uind Sum of Amata

DISCMM-1.CHP (8-95) 


\section{RELEASE AUTHORIZATION}

\begin{tabular}{|ll}
\hline Document Number: & HNF-SP-1105 REV 6 \\
\hline & $\begin{array}{l}\text { Hanford Fire Department FY } 99 \text { Annual Work Plan WBS } \\
6.5 .7\end{array}$ \\
Document Title: &
\end{tabular}

Document Title:

This document, reviewed in accordance with DOE Order 1430.1D, "Scientific and Technical Information Management," and DOE G 1430.1D-1, "Guide to the Management of Scientific and Technical Information," does not contain classified or sensitive unclassified information and is:

\section{APPROVED FOR PUBLIC RELEASE}

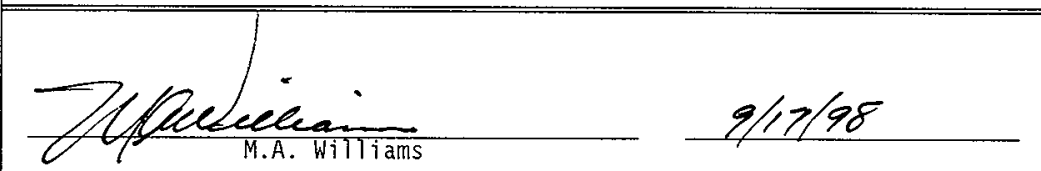

Lockheed Martin Services, Inc.

Document Control/Information Clearance

Reviewed for Applied Technology, Business Sensitive, Classified. Copyrighted, Export Controlled, Patent, Personal/Private, Proprietary, Protected CRADA. Trademark, Unclessified Controlled Nuclear Information.

LEGAL DISCLAIMER. This report was prepared as an account of work sponsored by an agency of the United States Government. Neither the United States Government nor any agency thereof, not any of their employees, nor any of their contractors, subcontractors or their employees, makes any warranty, express or implied, or assumes any legal liability or responsibility for the accuracy, completeness, or any third party's use or the resuls of such use of any information, apparatus, product, or process disclosed, or represents that its use would not infringe privately owned rights. Reference herein to any specific commercial product, process, or service by trade name, trademark, manufacturer. or otherwise. does not necessarily constitute or imply its endorsement, recommendation, or favoring by the United States Government or any agency thereof or jts contractors or subcontractors. The views and opinions of authors expressed herein do not necessarily state or reflect those of the United States Government or any agency thereof. This report has been reproduced from the best available copy. Printed in the United States of America. Available to the U.S. Department of Energy and its contractors from the U.S. Department of Energy Office of Scientific and Technical Information, P.O. Box 62, Oak Ridge, TN 37831; Telephone: 423/576-8401

Available to the public from the U.S. Department of Commerce National Technical Information Service, 5285 Port Royal Road, Springfield, VA 22161: Telephone: $703 / 487.4650$. 


\section{Distribution Sheet}

$\underline{\mathrm{RL}}$
C. P. Christenson
P. W. Kruger
S. J. Veitenheimer
J. D. Voice

A5-55

A5-54

A5-55

A5-55

EDH

R. C. Edmiston

H8-46

J. R. Bell

G1-15

H. M. Bucci

H8-69

T. J. Harper

H8-69

D. S. Kelly

H8-69

R. L. Shoup

H8-67

DynCorp Tri-Cities Services

M. D. Dallas

H5-33

R. S. Frix

H5-33

D. E. Good (8)

S3-97

C. L. Stice

E6-34

J. L. Williams

H5-33

M. B. Wilson

G3-24

LMSI

Document Processing \& Distribution

A3-89

Document Processing Center

A3-94

Central Files

A3-88 


\section{ANNUAL WORK PLAN APPROVAL SHEET}
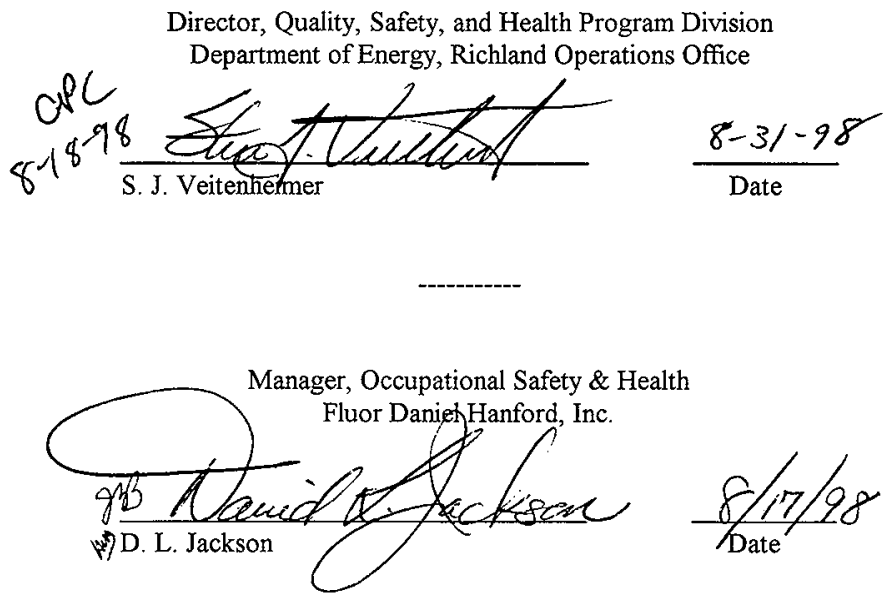

Director, Infrastructure

Fluor Daniel Hanford, Inc.

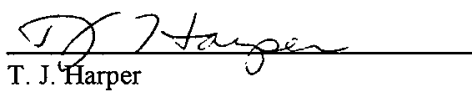

$$
\frac{8 / 18 / 98}{\text { Date }}
$$

Senior Vice President and General Manager

DynCorp Tri-Cities Services, Inc.

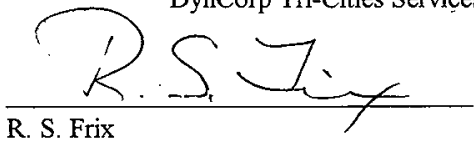

$$
\frac{8 / 14 / 98}{\text { Date }}
$$




\title{
DynCorp
}

DynCorp Tri-Cities Services, Inc.

Hanford Fire Department

\author{
FY 1999 \\ Annual Work Plan
}

August 1, 1998 


\section{Table of Contents}

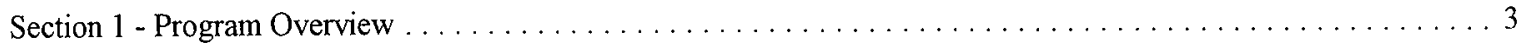

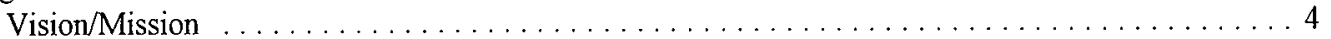

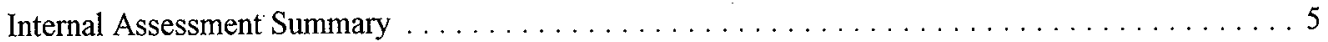

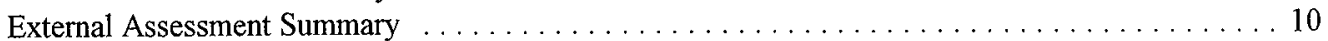

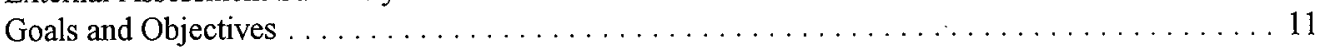

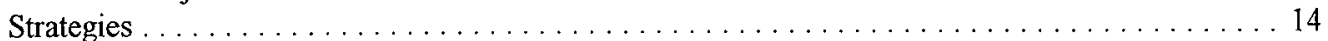

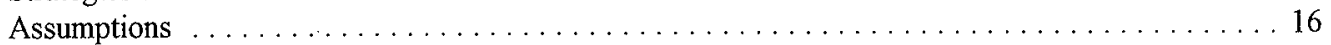

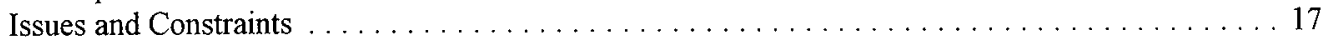

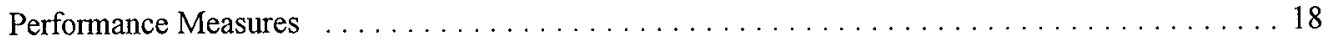

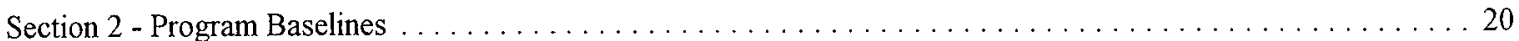

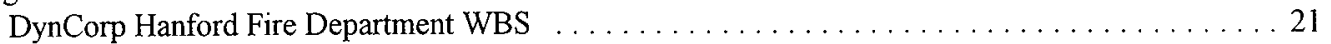

Work Breakdown Structure 6.5.7 FTE and Budget Summary Data $\ldots \ldots \ldots \ldots \ldots \ldots \ldots 22$

WBS 6.5 .7 Summary Data . . . . . . . . . . . . . . . . . . . . . . . . . . . 23

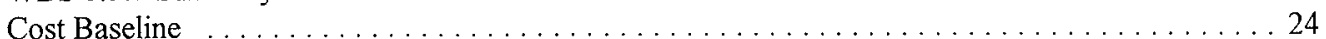

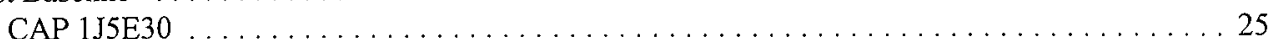

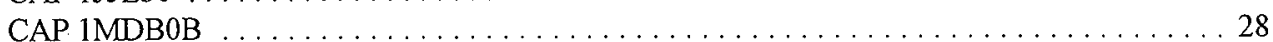

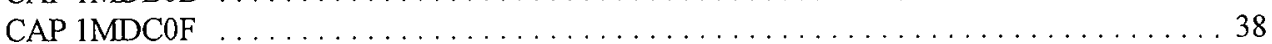

Work Breakdown Structure and Responsibility Assignment Matrix . . . . . . . . . 41

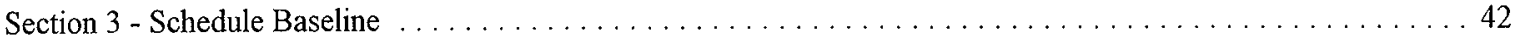

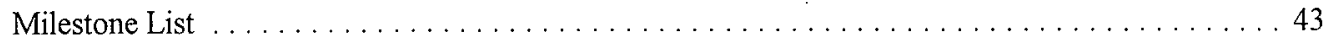

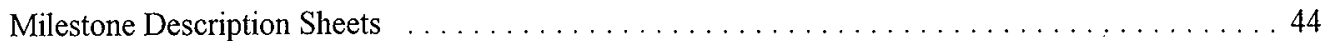




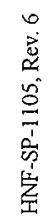
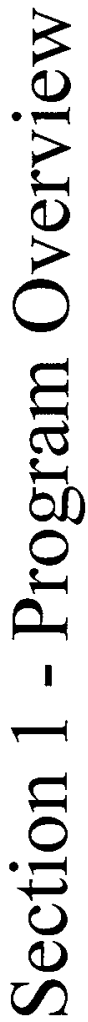


\begin{tabular}{|l|c|c|}
\hline & $\begin{array}{c}\text { DynCorp Tri-Cities Services, Inc. } \\
\text { Hanford Fire Department }\end{array}$ & FY 1999 \\
Pision/Mission & Program Plan & WBS No. 6.5.7 \\
\hline
\end{tabular}

The mission of the Hanford Fire Department (HFD) is to support the safe and timely cleanup of the Hanford site by providing a full range of services at the lowest possible cost to customers. These services include fire suppression, fire prevention, emergency rescue, emergency medical service, and hazardous materials response; and to be capable of dealing with and terminating emergency situations which could threaten the operations, employees, the general public, or interest of the U. S. Department of Energy operated Hanford Site. This includes response to surrounding fire departments/districts under mutual aid and state mobilization agreements and fire fighting, hazardous materials, and ambulance support to Washington Public Power Supply System (Supply System) and various commercial entities operating on site through Requests for Service from DOE-RL. The fire department also provides site fire marshal overview authority, fire system testing and maintenance, respiratory protection services, building tours and inspections, ignitable and reactive waste site inspections, prefire planning, and employee fire prevention education. 


\begin{tabular}{|l|c|c|}
\hline & DynCorp Tri-Cities Services, Inc. & FY 1999 \\
Internal Assessment Summary & Panford Fire Department & Anmual Work Plan \\
& WBS 6.5.7 & \\
\hline
\end{tabular}

\section{PrIMARY CUSTOMERS}

Fire department services are provided to DOE, its contractors and programs, and as requested by DOE, the Washington Public Power Supply System, the Bonneville Power Administration, private companies operating on site, and surrounding communities via mutual aid agreements.

\section{Products/Services Provided}

The fire department provides life safety and property protection services on a 24 hour a day, 7 day-a-week basis and services which assure fire system operability through the call-in of fire systems maintenance personnel to repair emergency failures.

\section{MAJor ACTIYITIES PERFoRMEd TO DELIVER PRODUCTS AND SERVICES}

The specific activities and services performed by the fire department are described below:

Incident Command: The HFD has the responsibility to provide an integrated command post capable of synchronizing all actions and elements for management and control of site emergencies. Responsibilities include acting on behalf of the Building Emergency Director/Building Warden in his/her absence to take the necessary actions to manage and control emergencies.

Fire Suppression: In firefighting operations, the fire department's fire suppression effectiveness is put to the ultimate test. All of the activities used by the fire department must come together on the fireground. The HFD is trained, staffed, and equipped to suppress any credible fire threat to the Hanford site. This includes special purpose building fires, structure fires, nuclear facility fires, and range or wildland fires. 


\begin{tabular}{|c|c|c|}
\hline $\begin{array}{c}\text { Internal Assessment Summary } \\
\text { (cont.) }\end{array}$ & $\begin{array}{c}\text { DynCorp Tri-Cities Services, Inc. } \\
\text { Hanford Fire Department } \\
\text { Program Plan } \\
\text { WBS 6.5.7 }\end{array}$ & $\begin{array}{c}\text { FY 1999 } \\
\text { Annual Work Plan }\end{array}$ \\
\hline
\end{tabular}

Emergency Rescue: Rescue operations are the most important consideration at any fire or emergency incident and is the only acceptable reason for exposing firefighters to otherwise unnecessary risks. Hanford fire crews maintain the capability for emergency rescue from fire, building collapse, excavation cave in, confined space, vehicle accidents, and any other accident event requiring rescue services.

Emergency Medical Services: These services are provided by utilizing the fire suppression personnel and cross-training them to be able to perform these essential life support tasks. These services includes basic and advanced life support. Basic life support is generally limited to airway maintenance, ventilatory (breathing) support, CPR (cardio-pulmonary resuscitation), hemorrhage control, splinting of fractures, management of spinal injuries, stabilization and transportation of the patient. Advanced life support services include all basic life support measures plus invasive medical procedures, including: intravenous therapy; cardiac defibrillation; administration of antiarrhythmic medications and other specific drugs, medications, and solutions; use of adjunctive ventilation devices; and all other procedures authorized by Washington State Law.

Hazardous Materials Response: This service is provided to the Hanford Site by utilizing selected suppression personnel, who are cross-trained and certified to perform this essential activity. Included in this service is emergency response to all site hazardous material spills and releases for control actions. These actions involve containment, confinement, and termination of emergency situations to best protect the site employees, facilities, and the environment.

Chemical/Biological Response. Provide initial emergency response, monitoring, decontamination, emergency medical treatment and patient transport in the event of a chemical/biological terrorist attack or other chemical/biological material release.

Mutual Aid Response: This service is provided through written fire suppression and emergency medical plans and agreements with 10 different agencies, including surrounding fire districts, cities, and counties. 


\begin{tabular}{|c|c|c|}
\hline $\begin{array}{c}\text { Internal Assessment Summary } \\
\text { (cont) }\end{array}$ & $\begin{array}{c}\text { DynCorp Tri-Cities Services, Inc. } \\
\text { Hanford Fire Department } \\
\text { Program Plan } \\
\text { WBS 6.5.7 }\end{array}$ & $\begin{array}{c}\text { FY 1999 } \\
\text { Annual Work Plan }\end{array}$ \\
\hline
\end{tabular}

Fire Sustem Testing and Maintenance Activities: Fire alarm, fire suppression, and fire water distribution system testing is a service provided to all Hanford site DOE contractors and agencies. Fire systems maintenance and repair services are provided for all PHMC contractor facilities, for Bechtel, the Bonneville Power Administration Ashe Substation, and the 313 Building operated by Kaiser Aluminum. Services include: functional testing of fire systems components, systems and devices in 482 Hanford buildings and facilities; and corrective and preventive maintenance of approximately 14,280 fire alarm and suppression system devices.

Self-Contained Breathing Apparatus (SCBA) and Powered Air Purified Respirator (PAPR) maintenance and servicing: These services are provided to all Hanford contractors who own and operate SCBA and PAPR units. The service includes annual and biannual inspections and functional tests of each of the approximately 550 SCBA units, 100 MSA pressure-demand dual twin respirators, over 600 high pressure breathing air cylinders, and over 300 PAPR units located throughout the Hanford Site, plus the cleaning and recharging of approximately 4,200 units and cylinders per year.

Fire Prevention Progzam: This program is specifically authorized by DOE-RL and is administered as a part of the site fire protection program by the fire marshal. The fire marshal provides fire prevention, fire investigation, and fire and life safety education services using nationally recognized codes and standards. The elimination of fire causes and the ability to reduce potential injuries and to minimize losses when fires do occur is of the utmost priority.

Response Readiness Training. This is a critical element for maintaining the required, ongoing training for emergency response personnel to assure response readiness. This activity is responsible for ensuring that personnel attain and retain the required local and state qualifications and certifications. This task coordinates Hanford Site interface drills and exercises that encompass unique facility hazards that assure rapid and knowledgeable response to safely mitigate site emergencies. 


\begin{tabular}{|c|c|c|}
\hline $\begin{array}{c}\text { Internal Assessment Summary } \\
\text { (cont.) }\end{array}$ & $\begin{array}{c}\text { DynCorp Tri-Cities Services, Inc. } \\
\text { Hanford Fire Department } \\
\text { Program Plan } \\
\text { WBS 6.5.7 }\end{array}$ & $\begin{array}{c}\text { FY 1999 } \\
\text { Annual Work Plan }\end{array}$ \\
\hline
\end{tabular}

\section{EVAlUation OF MAJOR ACTIVITIES (COST, VALUE-ADdED, ETC.)}

The services provided by the HFD, contribute directly to the safety of site personnel and facilities. Property loss is kept to a minimum, and personnel sickness or injuries are reduced in severity by providing prompt response of a well trained emergency response organization. Costs of emergency and fire systems testing services are shared by contractors through the common support pool and are kept very reasonable by having one organization with many cross-trained people able to fill a number of different emergency roles. Fire systems are tested and maintained to the requirements of national codes and standards by an efficient and cost effective organization established in response to a value engineering activity. Fire systems maintenance is funded through a service assessment pool with costs based upon the fire systems equipment in a given customer's facilities.

Building Tours and Inspections: Tours and inspections are conducted to familiarize suppression firefighters with building contents and any construction hazards of Hanford facilities and construction sites. These inspections include looking for code violations and potential fire hazards.

Prefire Planning: A prefire plan is an essential survey of a potential fire hazard and a plan for fighting a fire that might occur in a particular occupancy or facility. This service is provided by the fire suppression personnel and is a sitewide service. The prefire planning process involves four steps: 1) information gathering; 2) information analysis; 3) information dissemination, and 4) review and fire scene training drills. The individual facility/building layout showing access routes, dimensions, fire systems, exposures, and fire hydrants. Details include the type of occupancy, special volatile materials and construction of adjacent buildings and the best position to station fire apparatus in relation to water supply, space, grade, and to protect exposures. 


\begin{tabular}{|c|c|c|}
\hline \multirow{2}{*}{$\begin{array}{c}\text { Internal Assessment Summary } \\
\text { (cont.) }\end{array}$} & $\begin{array}{c}\text { DynCorp Tri-Cities Services, Inc. } \\
\text { Hanford Fire Department } \\
\text { Program Plan } \\
\text { WBS 6.5.7 }\end{array}$ & $\begin{array}{c}\text { FY 1999 } \\
\text { Annual Work Plan }\end{array}$ \\
\hline
\end{tabular}

\section{FACTORS WHich INFLUENCE RESOURCE CONSUMPTION (CHANGES TO COST AND VOLUME)}

$\sqrt{ }$ Frequently, deactivated facilities involving radioactive or hazardous materials require fire systems to remain in service that require servicing, testing, and maintenance. These fire protection systems cannot be deactivated until the fire systems are no longer required (as demonstrated by analysis) to minimize the effects of fires involving hazardous/radioactive materials, which could effect the public or environment, and when life safety of personnel is not a driving consideration.

$\checkmark$ As testing and maintenance requirements (defined by NFPA codes and standards) change, the cost of compliance changes. In recent years, the number of testing and maintenance functions and frequency requirements have changed.

$\checkmark$ During building construction and demolition, the risk of worker injury increases, often necessitating the pre-positioning of an on-the-scene ambulance and rescue team or mobile first aid facility. Because of these factors the staffing and funding requirements of the HFD are expected to remain near constant or grow slightly over the next five years.

$\checkmark$ As non-DOE contractor customers are added to support the HFD Funding levels and revenue generating activities increase, the costs to pool customers are reduced.

\section{Factors That INFLUence Changes in TYPES or NatURe or Products and SERVICES}

$\checkmark$ The type and nature of the services provided by the fire department will vary slightly as the site population and site mission changes, with more emphasis placed on medical, haz-mat, and rescue operations associated with the higher risk clean-up mission and demolition, recovery of structural materials, and construction. New buildings and systems are being activated while others are being removed from service with a net result of maintaining the status quo for the foreseeable future.

$\checkmark$ Occasional changes to National Fire Protection Association (NFPA) codes and standards, Washington Administrative Codes (WACs), CFR/OSHA requirements, or DOE Orders can cause significant impacts to the type and quantity of services required. If necessary, such changes are part of the budget request process during the year in which the changes are implemented. 


\begin{tabular}{|l|c|c|}
\hline External Assessment Summary & $\begin{array}{c}\text { DynCorp Tri-Cities Services, Inc. } \\
\text { Hanford Fire Department } \\
\text { Program Plan } \\
\text { WBS } 6.5 .7\end{array}$ & $\begin{array}{c}\text { FY 1999 } \\
\text { Annual Work Plan }\end{array}$ \\
\hline
\end{tabular}

\section{SUMMARY OF CUSTOMER REQUIREMENTS (NEEDS)}

The Hanford Fire Department meets the needs of DOE-RL, Hanford Site contractors, and other governmental and private business customers by providing timely emergency response services, reliable systems through testing and maintenance of fire systems, and an active fire prevention program. Meetings with DOE-RL occur several times monthly and meetings with site contractors occur at least twice monthly. These meetings are used as forums to discuss issues and services and to assure provided services meet customer expectations. Formal assessments such as Value Engineering studies, external audits, third party assessments, and reengineering studies are scheduled periodically to assure that our capabilities continue to meet customer desires and the requirements of DOE orders and appropriate national codes and standards. A third party assessment of site risks was conducted in FY 1996 at the request of RL. The results of this assessment are being used to help determine the site emergency service requirements for the next five to seven years and many of the recommendations of the assessment are being implemented at the direction of DOE-RL.

\section{OThER ExTERnal ChaLlenges}

As customer missions change, the HFD responds. For example, the increase in decontamination and decommissioning activities has previously prompted HFD to acquire an additional ambulance and to have crews stand by during the conduct of potentially hazardous demolition tasks. As private or non-DOE governmental agencies move on site or as site activities are privatized, HFD is negotiating to provide a full range of services to these entities. These services are currently being provided to the Washington Public Power Supply System reactor complex, Kaiser Aluminum (in the 300 Area's 313 Building), the Laser Interferometer Gravitational Wave Observatory (LIGO), Livingston Repair Company, and Washington State University. 


\begin{tabular}{|l|c|c|}
\hline Goals and Objectives & $\begin{array}{c}\text { DynCorp Tri-Cities Services, Inc. } \\
\text { Hanford Fire Department } \\
\text { Program Plan } \\
\text { WBS } 6.5 .7\end{array}$ & $\begin{array}{c}\text { FY 1999 } \\
\text { Annual Work Plan }\end{array}$ \\
\hline
\end{tabular}

\section{General Goals and OBJectives:}

The goals and objectives of the HFD are the preservation of life by immediate, on-the-scene emergency medical treatment of the sick and injured, control and mediation of hazardous materials and rescue operations, and the extinguishment of fires within the 560-square miles of the Hanford Site, and continuation of active testing, maintenance and prevention programs that minimize potential property losses and eliminate unsafe conditions. The HFD also has the objective to meet or exceed all federal, state, and DOE-mandated standards, requirements, and guidelines.

The general goals of the HFD are:

$\checkmark$ Provide Incident Command on all site emergency events.

$\checkmark$ Provide adequate fire protection at the lowest possible cost

$\sqrt{ }$ Reduce fire risks for the site

$\checkmark$ Provide rescue capabilities

$\sqrt{ }$ Control fire losses through ongoing prevention activities and programs

$\sqrt{ }$ Achieve fire safety awareness at all levels of the Hanford Site

$\checkmark$ Provide emergency medical life support services

$\sqrt{ }$ Provide hazardous materials control services

$\checkmark$ Provide initial emergency response, monitoring, decontamination and emergency medical treatment in the event of a chemical/biological terrorist attack or other chemical materials release

$\checkmark$ Provide testing and maintenance that assures properly functioning fire systems

$\sqrt{ }$ Provide mutual aid services

$\checkmark$ Reduce overlapping services to other programs and organizations

$\checkmark$ Provide SCBA/PAPR life safety maintenance and repair services 


\begin{tabular}{|l|c|c|}
\hline & $\begin{array}{c}\text { DynCorp Tri-Cities Services, Inc. } \\
\text { Hanford Fire Department } \\
\text { Program Plan } \\
\text { WBS } 6.5 .7\end{array}$ & $\begin{array}{c}\text { FY 1999 } \\
\text { Annual Work Plan }\end{array}$ \\
\hline
\end{tabular}

\section{SPECIFIC OBJECTIVES:}

Incident Command - Provide a training and qualified team of emergency response and incident command personnel

Fire Suppression - Provide a well-trained, effective fire suppression force for the preservation of life and property as related to the Hanford Site.

Emergency Rescue - Maintain a well-trained, ready to respond emergency force for rescue operations and preservation of life.

Emergency Medical Services - Provide both basic and advanced life support services to all personnel located on the Hanford Site.

Fire Alarm System Testing - Provide sitewide fire alarm and suppression system testing to assure the operability of installed fire systems.

Hazardous Materials Response - Provide emergency response capabiiities to control, contain, confine, and terminate the emergency situations in a manner that protects the site employees, facilities, and the environment.

Chemical/Biological Material Response - Provide initial emergency response capability to monitor, decontaminate, provide emergency treatment and transport patients in the event of a chemical/biological release.

Mutual Aid Response - Provide, when requested, emergency fire suppression and medical resources to the surrounding cities, fire districts and counties as per pre-approved mutual aid agreements. 


\begin{tabular}{|c|c|c|}
\hline & $\begin{array}{c}\text { DynCorp Tri-Cities Services, Inc. } \\
\text { Ganford Fire Department } \\
\text { Program Plan }\end{array}$ & $\begin{array}{c}\text { FY 1999 } \\
\text { WBS } 6.5 .7\end{array}$ \\
\hline
\end{tabular}

Breathing Apparatus Maintenance - Provide factory trained personnel to pickup, deliver, maintain and overhaul all site SCBA units, powered air purified respirators, and high-pressure breathing air cylinders.

Fire Systems Maintenance - Maintain a trained and qualified multi-disciplined organization to maintain and upgrade fire systems and to assure that failed systems are returned to service in a timely and efficient manner.

Building Tours and Inspections - Provide well-trained personnel to perform sitewide building and construction site inspections.

Prefire Planning - Conduct prefire planning on all high hazard areas and facilities on an annual basis and all other facilities/buildings as per HFD prescribed schedules for updating and maintaining current information for strategic planning of emergency operations on the Hanford Site.

Fire Prevention Program - Provide code compliance inspection and overviews of all facilities, buildings, and construction sites for the purpose of preventing fires from occurring and reduce the dollar loss in the ones that do occur.

Response Readiness. Training - Provide high quality training to all fire department members and act as the interface for establishing drills, exercises, and tabletop schedules with on- and off-site organizations. 


\begin{tabular}{|l|c|c|}
\hline \multirow{2}{*}{ Strategies } & $\begin{array}{c}\text { DynCorp Tri-Cities Services, Inc. } \\
\text { Hanford Fire Department } \\
\text { Program Plan } \\
\text { WBS } 6.5 .7\end{array}$ & $\begin{array}{c}\text { FY } 1999 \\
\text { Annual Work Plan }\end{array}$ \\
\hline
\end{tabular}

\section{CUSTOMER SUPPORT STRATEGIES}

$\checkmark$ Provide fire suppression, emergency rescue, emergency medical services, building tours and inspections, prefire planning, and fire prevention activities from the 100 Area fire station with a Monday through Friday, 10-hour per day pumper crew and ambulance crew and a medical crew standing by during off-shift hours to support current needs. Extended and additional services can be provided (within existing staffing levels) to cover off-shift or weekend high risk activities if requested and paid for by customers in the 100 Areas.

$\checkmark$ Provide incident command, fire suppression, emergency rescue, emergency medical services, hazardous materials response capabilities, building tours and inspections, prefire planning, and fire prevention activities from the 200,300 , and 400 Areas Fire Stations with a 24-hour per day pumper crew (2) and ambulance crew.

$\checkmark$ Provide fire system maintenance support to customer organizations through a single multi-craft, multi-disciplined organization staffed with craft, engineers, planners/schedulers, and supporting firefighters.

$\sqrt{ }$ Provide a fire prevention program for the purpose of preventing most site fires from occurring and reducing the losses of the ones that do occur.

$\sqrt{ }$ Provide fire protection systems operational assurance and acceptance testing support for fire alarm and fire suppression systems and components. Other services include deactivation and reactivation of fire systems as required to accomplish facility tasks.

$\checkmark$ Provide 24-hour-a-day dispatch capabilities. This task encompasses the timely dispatch of emergency responses to both onsite emergencies and offsite mutual aid emergencies. 


\begin{tabular}{|l|c|c|}
\hline & $\begin{array}{c}\text { DynCorp Tri-Cities Services, Inc. } \\
\text { Hanford Fire Department } \\
\text { Protegies (cont.) }\end{array}$ & $\begin{array}{c}\text { FY 1999 } \\
\text { Annual Work Plan }\end{array}$ \\
\hline
\end{tabular}

$\checkmark$ Provide innovative program management through diversification and utilization of all available resources. Program management has adapted to the change-oriented environment and will continue to support the new mission at Hanford.

$\sqrt{ }$ Remain efficient and cost-effective through continuous periodic self-assessment, customer feedback, and external assessment by independent third party sources.

$\sqrt{ }$ Provide current information to site customers and the public regarding the emergency services capabilities of the department through the use of a home page on the World Wide Web.

$\sqrt{ }$ Produce a service demonstration video to showcase the full range of emergency and support services provided by the Hanford Fire Department to customer organizations.

$\sqrt{ }$ Provide all possible support for implementing the recommendations of the reengineering analysis of Hanford Site incident command.

$\checkmark$. Maintain compliance with the site's Part B permit as related to emergency response capabilities.

\section{ORGaNIZATION AND MANAGEMENT STRATEGIES}

Constantly seek self-improvement through employee involvement in an enthusiastic total quality program encompassing productivity improvement programs, the Behavior Based Safety Program, the Voluntary Protection Program, self-assessments, and team building. 


\begin{tabular}{|l|c|c|}
\hline \multirow{2}{*}{ Assumptions } & $\begin{array}{c}\text { DynCorp Tri-Cities Services, Inc. } \\
\text { Hanford Fire Department } \\
\text { Program Plan } \\
\text { WBS } 6.5 .7\end{array}$ & $\begin{array}{c}\text { FY 1999 } \\
\text { Annual Work Plan }\end{array}$ \\
\hline
\end{tabular}

$\checkmark$ The level and type of services provided to site customers in FY 1999 will be consistent with service levels provided during the last quarter of FY 1998.

$\checkmark$ HFD will continue to supply the same range of services as currently provided in the 313 building for Kaiser Aluminum company and for the Washington Public Power Supply System complex, LIGO, LRC and WSU, as defined in the respective contractual agreements

$\checkmark$ Implementation of the recommendations generated by the third party needs assessment will continue as defined in the DOE-RL approved implementation plan prepared by the HFD.

$\checkmark$ The maintenance of PNNL, WPPSS and FFTF fire protection systems is not part of the work tasks covered by this document. Maintenance of the fire systems in these facilities could, through negotiations and DOE support, be picked up by the HFD as part of a future cost-savings initiative. 


\begin{tabular}{|l|c|c|}
\hline Issues and Constraints & $\begin{array}{c}\text { DynCorp Tri-Cities Services, Inc. } \\
\text { Hanford Fire Department } \\
\text { Program Plan } \\
\text { WBS } \mathbf{6 . 5 . 7}\end{array}$ & $\begin{array}{c}\text { FY 1999 } \\
\text { Annual Work Plan }\end{array}$ \\
\hline
\end{tabular}

$\checkmark$ Implementation of the new NFPA 1582 Firefighter Medical Requirements will require negotiations with HAMTC firefighters and a risk management review by Legal and Labor Relations regarding the impacts of this new standard on the existing work force; e.g., emergency response personnel retirement and disability options

$\sqrt{ }$ Implementation of the NFPA 1500 physical fitness requirements for firefighters will require negotiations with HAMTC firefighters and a risk management review by Legal and Labor Relations regarding the impacts on the existing work force; e.g., emergency response personnel retirement and disability options.

$\checkmark$ It is anticipated that during this fiscal year, HFD personnel will be asked to participate in numerous HAMMER-related support activities. That workscope is not included in this plan and will have to be addressed via change control once task scoping activities are completed. 


\begin{tabular}{|l|c|c|}
\hline & DynCorp Tri-Cities Services, Inc. & FY 1999 \\
Performance Measures & Hanford Fire Department & Annual Work Plan \\
& Wrogram Plan & 6.5 .7 \\
\hline
\end{tabular}

The fire department routinely reports on several different performance measures. The specific performance measures reported, the frequency report, and the organizations reported to are provided below:

\section{Performance Measures}

Fire Alarm Responses

Ambulance Runs

Respiratory Protection Maintenance Statistics

Training; given and received

Complete $100 \%$ of fire system testing for the year

Complete $100 \%$ of fire systems preventive maintenance for the year

Budget status

\section{Report Frequency}

Monthly

Monthly

Monthly

Monthly

Monthly

Monthly

Monthly

\section{Organization Reported To}

Building managers, company senior staff, and DOE-RL

Building managers, company senior staff, and DOE-RL

Building managers, company senior staff, and DOE-RL

Building managers, company senior staff, and DOE-RL

Building managers, company senior staff, and DOE-RL

Building managers, company senior staff, and DOE-RL

Company senior staff and DOE-RL 


\begin{tabular}{|l|c|c|}
\hline & DynCorp Tri-Cities Services, Inc. & FY 1999 \\
Performance Measures (cont.) & Hanford Fire Department & Annual Work Plan \\
& Program Plan & \\
\hline
\end{tabular}

\section{Performance Measures}

Complete $90 \%$ of special inspections during the month in which they are scheduled.

Complete $90 \%$ of building tours during the quarter in which they are scheduled.

Delivery of $95 \%$ of fire prevention training during the month it is scheduled

Investigate $100 \%$ of reported fires during the month they are reported

Process $100 \%$ of fire permits within three working days of date requested
Report Frequency

Monthly

Quarterly

Monthly

Monthly

Monthly

\section{Organization Reported To}

Building Managers, Company Senior Staff, and DOE-RL

Building Managers, Company Senior Staff, and DOE-RL

Building Managers, Company Senior Staff, and DOE-RL

Building Managers, Company Senior Staff, and DOE-RL

Building Managers, Company Senior Staff, and DOE-RL 
HNF-SP-1 105, Rev

\section{Section 2 - Program Baselines}




\section{DynCorp Hanford Fire Department WBS}

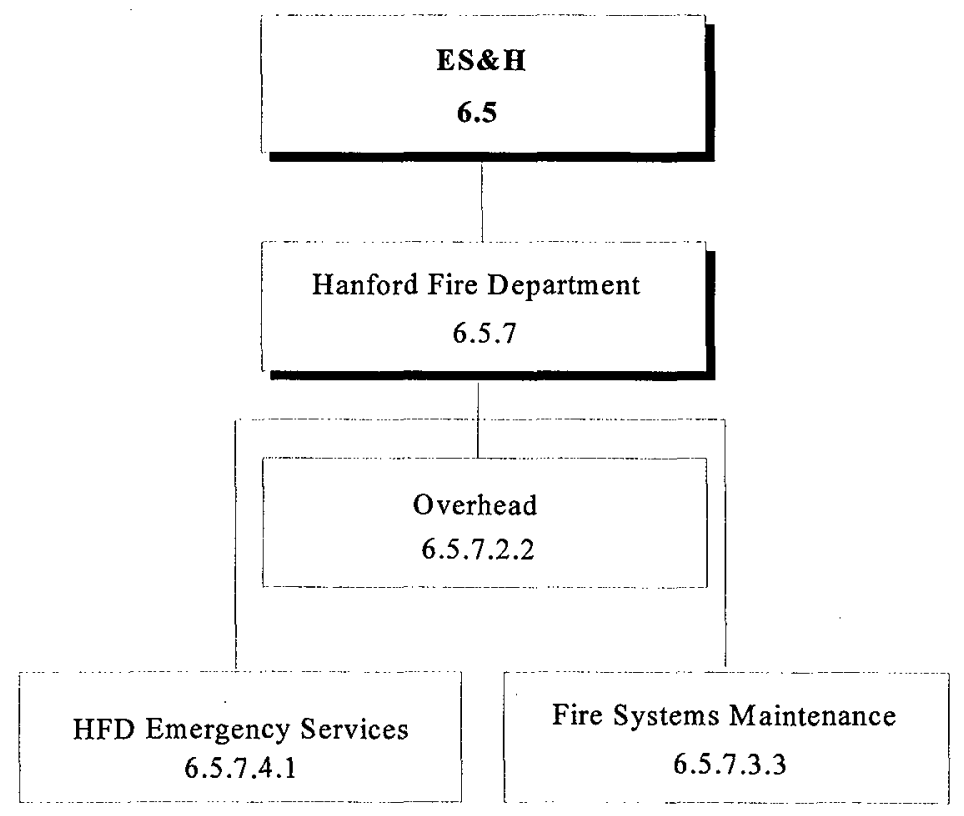


Work Breakdown Structure 6.5.7 FTE and Budget Summary Data

\begin{tabular}{|c|c|c|c|c|c|c|c|c|c|}
\hline Organization & WBS & CAP \# & $\begin{array}{l}\text { Org } \\
\text { FTE }\end{array}$ & $\begin{array}{c}\text { Support } \\
\text { FTE }\end{array}$ & Total FTE & \multicolumn{2}{|c|}{ Net \$K } & \multicolumn{2}{|c|}{ Total $\$ K$} \\
\hline \multicolumn{10}{|c|}{$6.5 .7 \mathrm{DOH}$} \\
\hline Hanford Fire Department & 6.5 .7 .2 .2 & $1 \mathrm{~J} 5 \mathrm{E} 30$ & 4 & 0 & 4.0 & $\$$ & 293.4 & $\$$ & $2,572.2$ \\
\hline \multicolumn{10}{|c|}{ 6.5.7 Indirect } \\
\hline HFD Emergency Services & 6.5 .7 .4 .1 & $1 \mathrm{MDB} 0 \mathrm{~B}$ & 107 & 3.2 & 110.2 & $\$$ & $7,441.0$ & & $11,053.7$ \\
\hline Fire Systems Maintenance & 6.5 .7 .3 .3 & $1 \mathrm{MDCOF}$ & 23 & .9 & 23.9 & $\$$ & $1,990.0$ & $\$$ & $2,867.5$ \\
\hline \multicolumn{3}{|l|}{ TOTALS (DOH \& Indirect) } & 134 & 4.1 & 138.1 & $\$$ & $9,725.0$ & & $16,493.4$ \\
\hline
\end{tabular}




\section{WBS 6.5.7 Summary Data}

\begin{tabular}{|c|c|c|c||}
\hline Organization & Indirect FTE & $\begin{array}{c}\text { Direct } \\
\text { FTE }\end{array}$ & Total FTE \\
\hline Hanford Fire Department & 138.1 & 5 & 143.1 \\
\hline Total & $\mathbf{1 3 8 . 1}$ & $\mathbf{5}$ & $\mathbf{1 4 3 . 1}$ \\
\hline
\end{tabular}


0
0
0
0
0
0
0
0
0
0
0

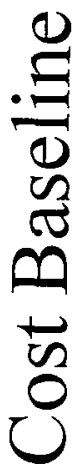




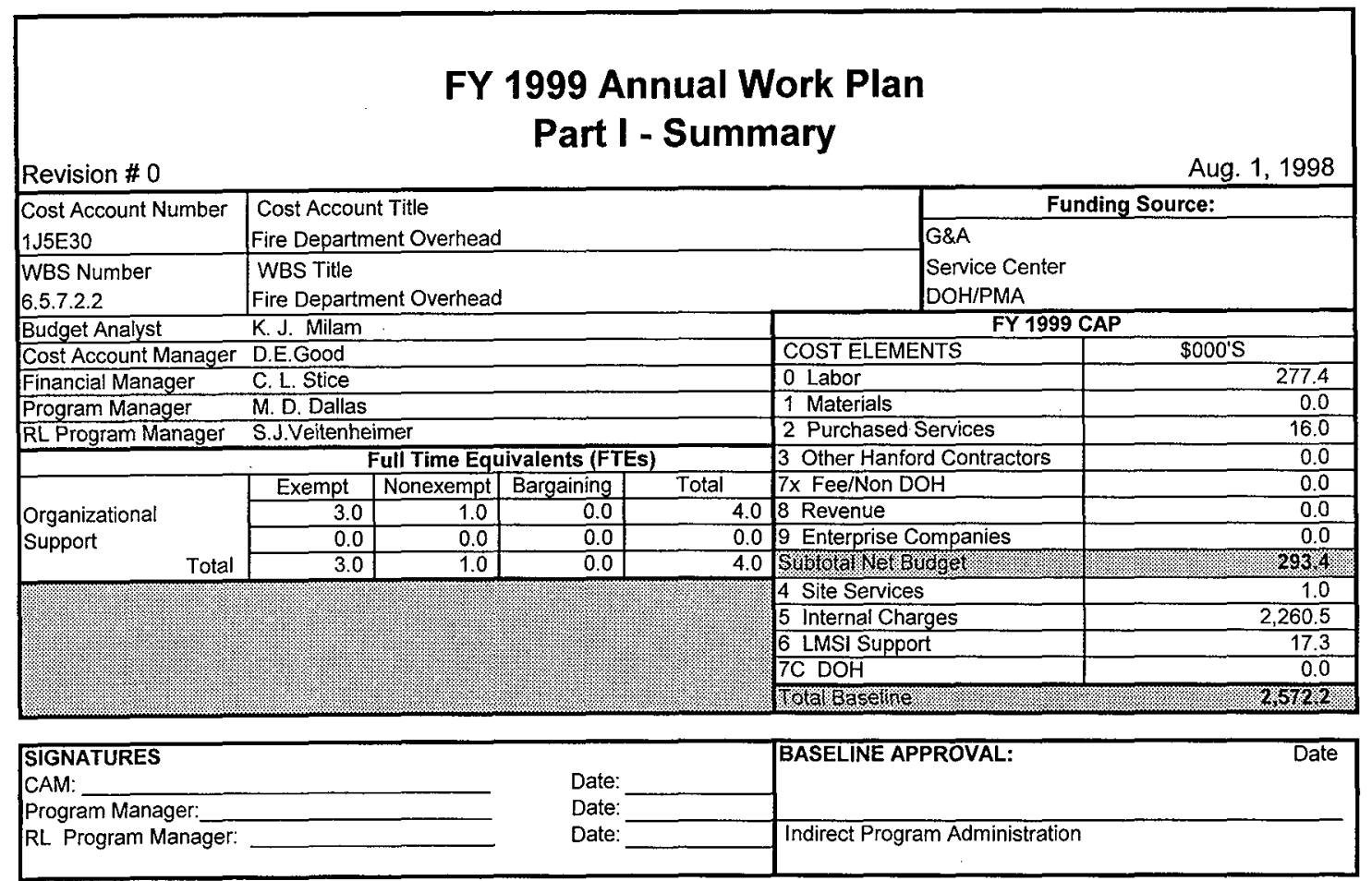

Hanford Fire Department Annual Work Plan, WBS 6.5.7, Page 25 


\section{FY 1999 Annual Work Plan}

Part II - Activity Detail

\section{COST ACCOUNT WORKSCOPE SUMMARY}

Fire Department Chief and Support Staff

\section{APPROVED BASELINE:}

Activity Description

This task addresses the Chief of the Hanford Fire Department, the department secretary, the fire department specialist, the department program specialist. This group provides management, administrative, and financial services for the department. The Chief functions as the interpretive authority for S/RID for fire department program matters for DOE-RL. The Chief is the senior fire command officer for mitigation of all site emergencies. The task also performs preparation and management of department budget and finances, including the finance officer position on large fires; statistical analysis; data retrieval; trend analysis within fire department areas of responsibility; document and report preparation; definition and tracking of performance agreements, milestones, and other commitments; administrative control of files, records, disciplinary actions, and union interface materials.

Mutually Agreed Upon Workscope Deliverables and Due Dates

1 99-HFD-001, Third Party Needs Assessment Implementation, due 9/15/99

2 99-HFD-002, HFD Management Assessments, due 9/30/99

3 99-HFD-003, Medical Fitness Program Implementation, due 6/30/99

4 99-HFD-004, Pre-planning for an FY 2000 Update to the HFD Emergency Services Needs Assessment, due 3/01/99

5 99-HFD-005, HFD Customer Service Agreements, due 8/30/99

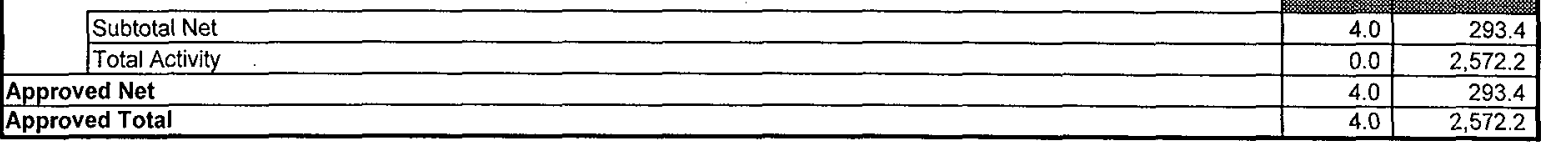




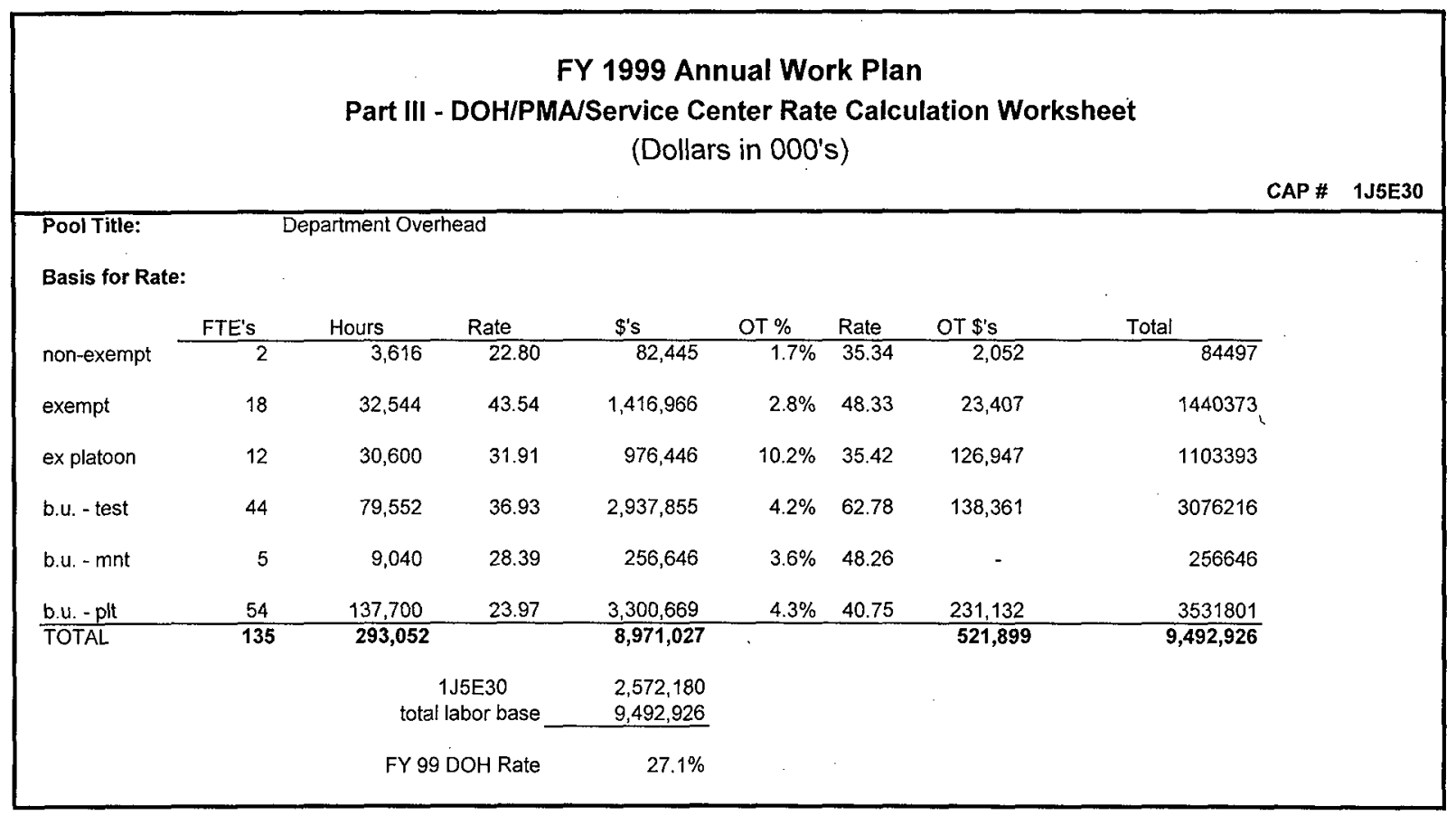




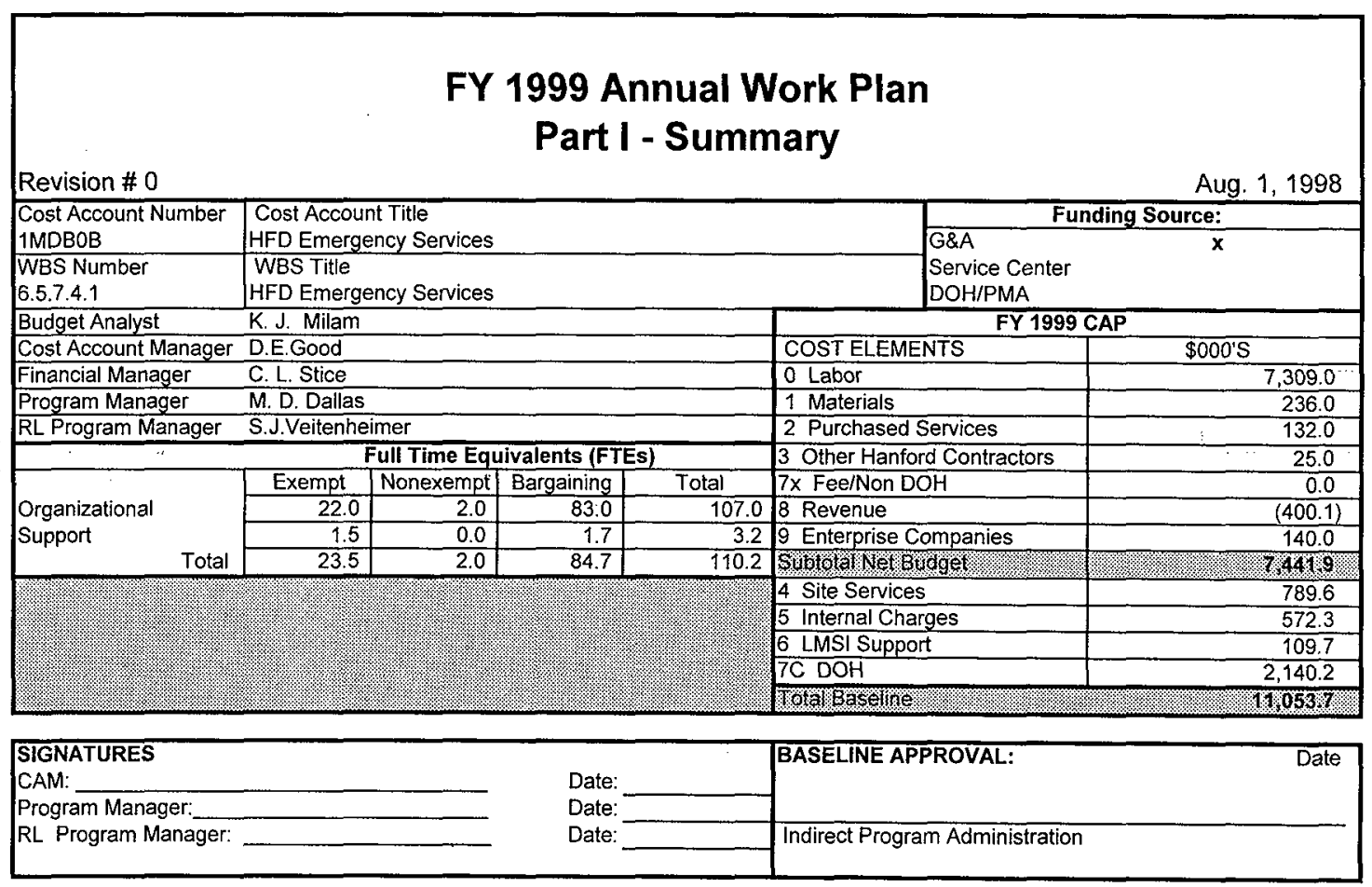




\section{FY 1999 Annual Work Plan}

Part II - Activity Detail

\section{COST ACCOUNT WORKSCOPE SUMMARY}

\section{Emergency Medical}

\section{APPROVED BASELINE:}

Activity Description

This task consists of providing basic and advanced life support. Basic life support is generally limited to airway maintenance, ventilatory (breathing) support, cardio-pulmonary (resuscitation) (CPR), hemorrhage control, splinting of fractures, management of spinal injuries, and protection and transport of the patient. Advanced life support services include all basic life support measures plus invasive medical procedures including: intravenous therapy; cardiac defibrillation; administration of antiarrhythmic medications and other drugs, medications and solutions; use of ventilation devices; and all other procedures authorized by

Washington State law. Personnel are trained and equipped to provide initial field treatment for exposure to nerve, blister, or other chemical weapons agents, and to transport casualties

Mutually Agreed Upon Workscope Deliverables and Due Dates None

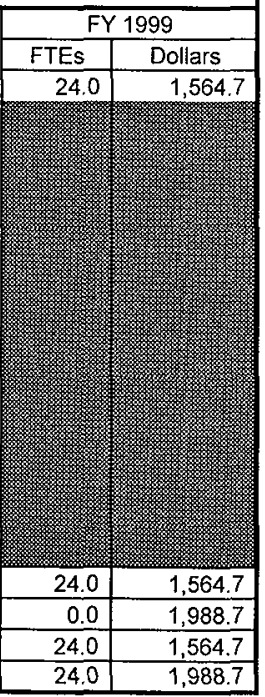

\section{Approved Net}

Subtotal Net

Approved Total 


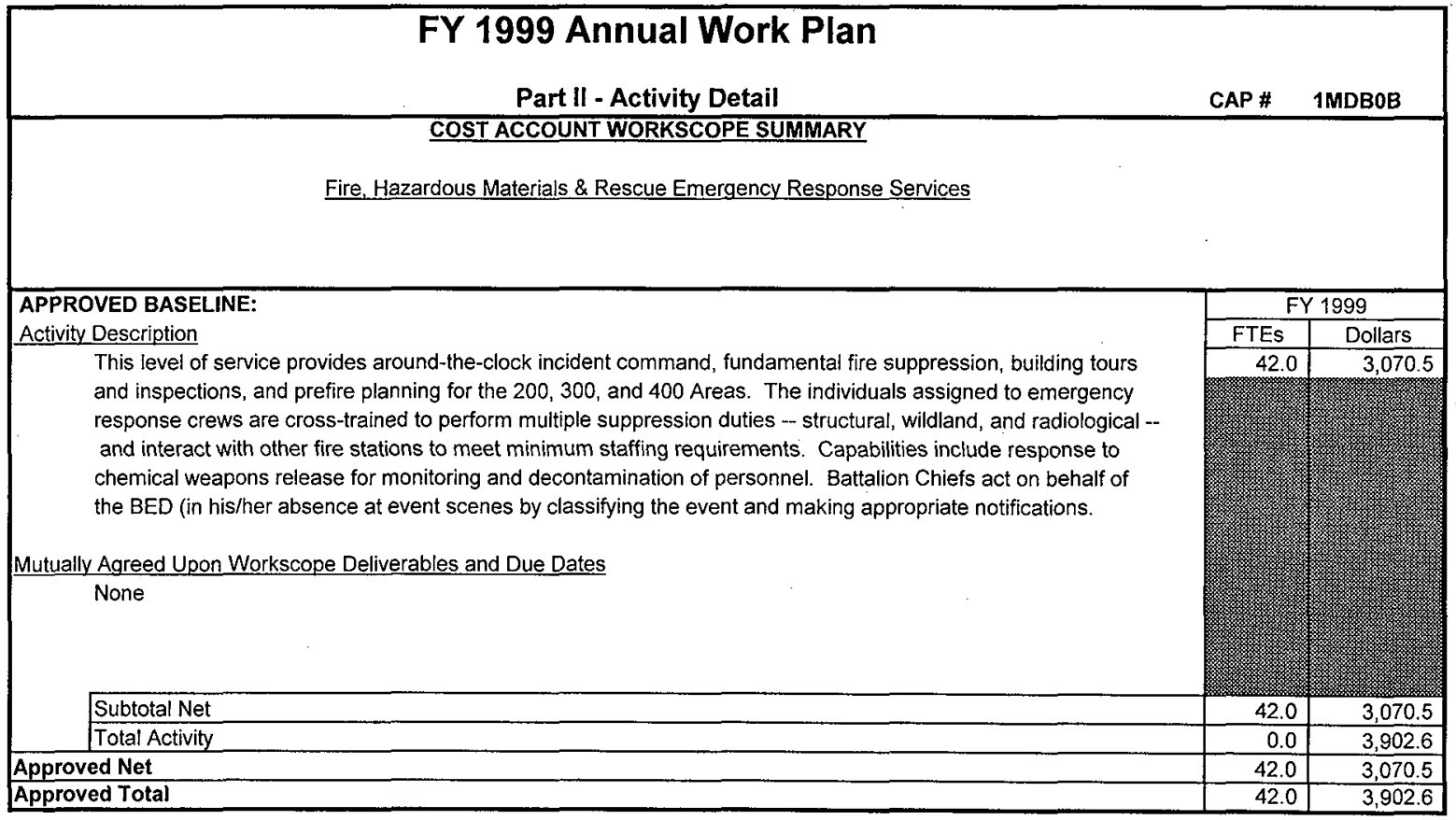




\section{FY 1999 Annual Work Plan}

Part II - Activity Detail

\section{COST ACCOUNT WORKSCOPE SUMMARY}

\section{Area Station - Fire \& Rescue Emergency Response Services}

\section{APPROVED BASELINE:}

\section{Activity Description}

This level of service provides dayshift fundamental fire suppression, building tours and inspections, and prefire planning for the 100 Areas. The individuals assigned to emergency response crews are cross-trained to perform multiple suppression duties -- structural, wildland, and radiological -- and interact with other fire stations to meet minimum staffing requirements. As long as significant programmatic activities and employee populations continue in the 100 Areas, emergency response capability there must be maintained. Several options were considered before the decision was made to provide services in the current manner. They include:

$>$ Response from the 200 Area station. This option was ruled out because the response time was too long in light of the additional time required before a sick or injured employee could receive initial "in-field" or "enroute" medical care. For example, the extra 10-12 minutes before an emergency medical responder was on scene could well mean the loss of life for an employee with a heart attack. Also, the delay in response to a fire in one of the radiologically contaminated facilities could lead to a loss of radiological containment and the off-site spread of contamination.

$>$ Closing the 100 Area station and housing emergency responders in another facility was considered but eliminated as an option because of the lack of a suitable building that had a climate-controlled garage-type bay for fire apparatus and suitable sleeping and eating spaces for 24-hour personnel.

> The third option considered and the one ultimately implemented was to reduce fire responder staffing to 5 days a week 10 hours a day, and to continue medical response 7 days a week, 24 hours a day - all services to be provided out of the current 100 Area fire station. Facility costs are being held to a minimum by doing only essential maintenance and not upgrades or enhancements will occur.

Mutually Agreed Upon Workscope Deliverables and Due Dates none

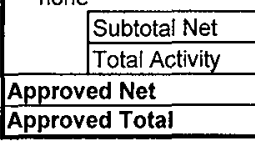

Approved Total 


\section{FY 1999 Annual Work Plan}

Part II - Activity Detail

CAP \#

1MDBOB

\section{COST ACCOUNT WORKSCOPE SUMMARY}

Fire Protection System Testing

\section{APPROVED BASELINE:}

Activity Description

This task provides functional testing of life safety and property fire protection systems in DOE-owned facilities on the Hanford Site. There are 530facilities on site with operating fire protection systems.

This task maintains the central auditable records for all fire system activity across the site. Firefighters performing this task are also cross-trained to perform as emergency responders, providing

immediate backup during emergencies.

Mutually Agreed Upon Workscope Deliverables and Due Dates

1 Milestone 99-HFD-012, Fire Systems Testing Completion, due 9/30/99

\begin{tabular}{|l|r|r|}
\hline Subtotal Net & 25.0 & $2,220.2$ \\
\cline { 2 - 3 } & Total Activity & 0.0 \\
\hline Approved Net & $4,310.7$ \\
\hline Approved Total & $2,220.2$ \\
\hline
\end{tabular}




\begin{tabular}{|c|c|c|}
\hline $\begin{array}{c}\text { FY } 1999 \text { Annual Work Plan } \\
\text { Part II - Activity Detail }\end{array}$ & CAP \# & 1MDB0B \\
\hline \multicolumn{3}{|l|}{ COST ACCOUNT WORKSCOPE SUMMARY } \\
\hline $\begin{array}{l}\text { APPROVED BASELINE: } \\
\text { Activity Description }\end{array}$ & \multicolumn{2}{|c|}{ FY 1999} \\
\hline $\begin{array}{l}\text { Activity Description } \\
\text { This task provides a site fire marshal's office which performs post-fire investigations; manages the site fire } \\
\text { protection permitting process; serves as the NFPA compliance officer; performs statistical analysis and } \\
\text { record-keeping of emergency responses; acceptance tests; provides a fire prevention program to the site; } \\
\text { provides fire safety education for site employees. Included is an Industrial hygienist who serves as the } \\
\text { technical liaison for site incidents and who helps train emergency responders in hazmat areas and who } \\
\text { performs a variety of safetyservices for the department that were previousiy purchased from others. } \\
\text { Mutually Agreed Upon Workscope Deliverables and Due Dates } \\
1 \text { Milestone 99-HFD-009, Ignitable/Reactive Waste Site Inspections, due 12/31/98. }\end{array}$ & FTEs & $\begin{array}{l}\text { Dollars } \\
314.9\end{array}$ \\
\hline Subtotal Net & 4.0 & 314.9 \\
\hline $\begin{array}{l}\text { Total Activity } \\
\end{array}$ & & 400.2 \\
\hline Approved Net & 4.0 & 314.9 \\
\hline Approved Total & 4.0 & 400.2 \\
\hline
\end{tabular}




\title{
FY 1999 Annual Work Plan
}

Part II - Activity Detail

\section{COST ACCOUNT WORKSCOPE SUMMARY}

\author{
Breathing Air Equipment Services
}

\section{APPROVED BASELINE:}

Activity Description

This site-wide program provides maintenance, testing, repair, modification and servicing of all site respiratory protection equipment. The service includes annual and biannual inspections and functional tests of approximately 550 self-contained breathing apparatus (SCBA) units, 100 Mine Safety Appliance Company (MSA)

pressure-demand dual twin respirators, over 600 high pressure breathing air cylinders, and over 300 powered air purifying respirator (PAPR) units located throughout the Hanford Site. Additional services include the cleaning and recharging of units and cylinders as required (approximately 4200 per year).

Mutually Agreed Upon Workscope Deliverables and Due Dates

1 Milestone 99-HFD-011, Testing of Respiratory Protection Equipment, due 8/31/99.

\begin{tabular}{|l|r|r|}
\hline Subtotal Net & 3.0 & 143.9 \\
\cline { 2 - 4 } & Total Activity & 0.0 \\
\hline Approved Net & 181.9 \\
\hline Approved Total & 143.9 \\
\hline
\end{tabular}




\title{
FY 1999 Annual Work Plan
}

Part II - Activity Detail

\section{COST ACCOUNT WORKSCOPE SUMMARY}

\author{
Response Readiness Training
}

\section{APPROVED BASELINE:}

Activity Description

The Response Readiness Training function is a critical element for maintaining the required, ongoing training for emergency response personnel to assure response readiness. This activity is responsible for ensuring that personnel attain and retain the required local and state qualifications and certifications. This task coordinates

Hanford Site incident command drills and exercises that encompass unique facility hazards that assure rapid and knowledgeable response to safely mitigate site emergencies. The mobile incident command post will be utilized for this training whenever applicable to assure personnel are trained in its use and that the vehicle is operational.

Mutually Agreed Upon Workscope Deliverables and Due Dates

1 Milestone 99-HFD-010, Qualifications/Certifications for Fire Department Emergency Medical Responders, due $9 / 15 / 99$

2 Milestone 99-HFD-006, Incident Command Post Operational Readiness, due 9/15/99

\begin{tabular}{|l|r|r|}
\hline Subtotal Net & 6.0 & 352.7 \\
\cline { 2 - 3 } & Total Activity & 0.0 \\
\hline Approved Net & 448.3 \\
\hline Approved Total & 6.0 & 352.7 \\
\hline
\end{tabular}




\section{FY 1999 Annual Work Plan}

Part II - Activity Detail

CAP \#

1MDBOB

\section{COST ACCOUNT WORKSCOPE SUMMARY}

Revenue Generation

\section{APPROVED BASELINE:}

\section{Activity Description}

This task consists of generating revenue by providing customers with a full range of fire department services, including

$>$ Incident command of any and all emergency events

$>$ Basic and advanced life support for ill or injured employees to include transportation to a local medical facility and enroute treatment.

$>$ Response to fires, including fires in radiation zones and building, wildland, and vehicle fires

$>$ High and low angle rescue

$>$ The acceptance and operational testing of fire alarm and suppression systems

$>$ A fire prevention program to include employee training on fire safety

$>$ Building occupancy permitting and burning permits

$>$ Fire safety tours of facilities

Mutually Agreed Upon Workscope Deliverables and Due Dates None

\footnotetext{
Subtotal Net Total Activity 


\section{FY 1999 Annual Work Plan}

\section{Part III - DOH/PMA/Service Center Rate Calculation Worksheet \\ (Dollars in 000's)}

CAP \# 1MDBOB

\section{Pool Title:}

HFD Emergency Services

Basis for Rate:

Fire Department services are accumulated in the PHMC Sitewide Support Pool.

1) Fire Department services provided to PHMC projects are distributed via the company level overhead rate

2) Fire Department service provided to other U.S. Department of Energy Contractors (e.g. PNNL) are deducted from the Fire Department account and charged to the other contractors at an allocation rate which is calculated on the replacement value of their facilities.

3) Fire Department services provided to non-RL customers (e.g. WPPSS, Kaiser Aluminum) are deducted from the Fire Department account and charged to a DOE-RL RFS at an amount which RL negotiated; or (LIGO and others) at an amount based on their headcount and an assessment of the risk/vulnerability of their facilities.

FY 1999 budget is based on a cost element-by-cost element analysis of past trends and estimated FY 1999 needs.

Revenue future of $\$ 400.1 \mathrm{~K}$ is an estimate of the total payments due from WPPSS, LIGO, and Kaiser Aluminum 


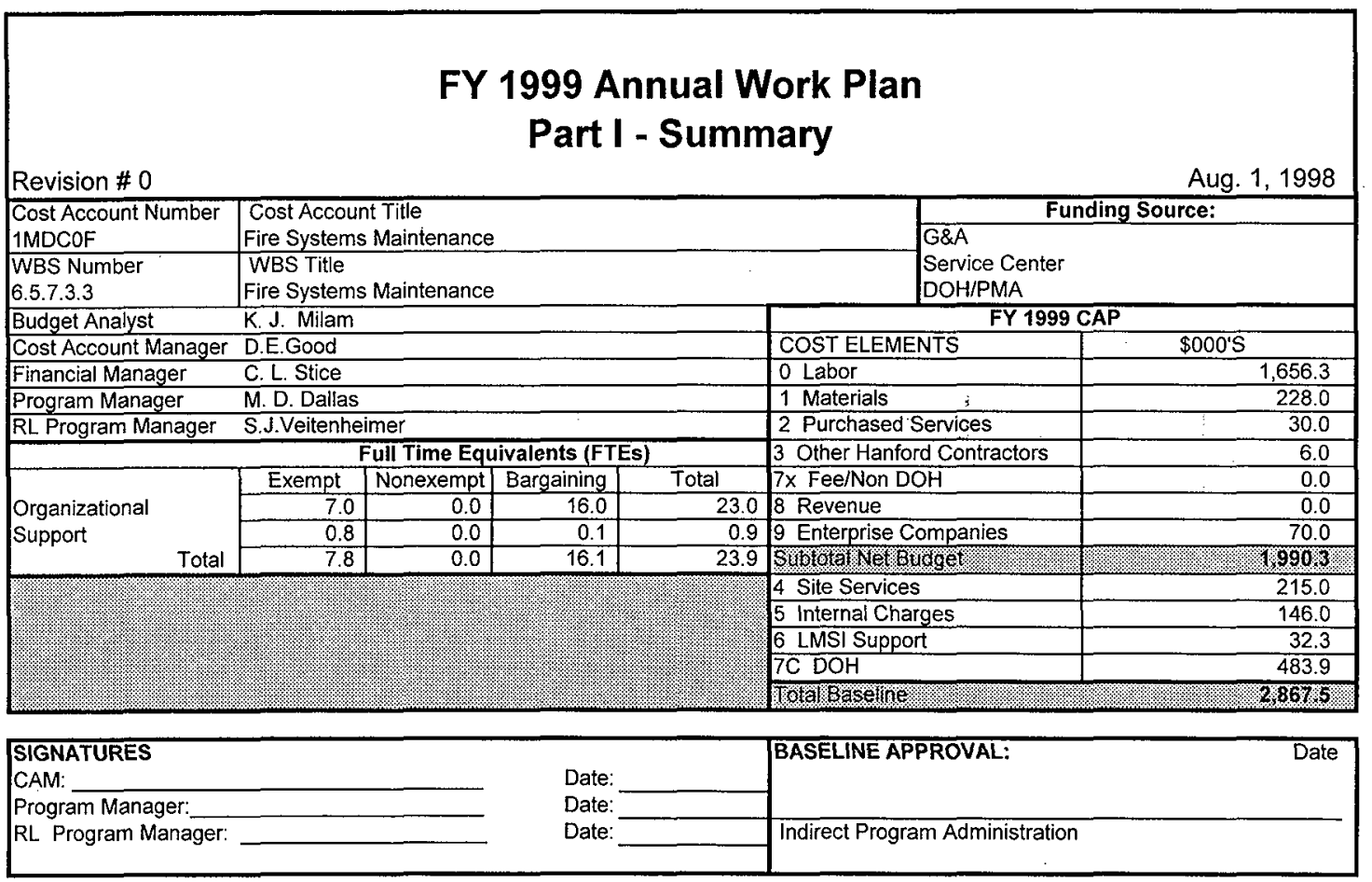




\begin{tabular}{|c|c|c|}
\hline $\begin{array}{l}\text { FY } 1999 \text { Annual Work Plan } \\
\text { Part II - Activity Detail }\end{array}$ & CAP \# & $1 \mathrm{MDCOF}$ \\
\hline \multicolumn{3}{|l|}{$\begin{array}{l}\text { COST ACCOUNT WORKSCOPE SUMMARY } \\
\text { Preventive maintenance and repair of fire alarm, fire suppression, fire water distribution and warning siren systems. }\end{array}$} \\
\hline \multirow{2}{*}{$\begin{array}{l}\text { APPROVED BASELINE: } \\
\text { Activity Description }\end{array}$} & \multicolumn{2}{|c|}{ FY 1999} \\
\hline & FTEs & Dollars \\
\hline $\begin{array}{l}\text { This activity provides preventive and repair maintenance to the site's fire alarm, fire suppression, fire water } \\
\text { distribution (12,800 pieces of equipment installed in } 468 \text { site facilities). This includes fire hydrants and gate valves. } \\
\text { It also develops and maintains site-wide maintenance procedures for these systems, performs engineering tasks } \\
\text { in support of maintenance activities, maintains a recall data base for periodically reoccurring tasks, and develops } \\
\text { work packages to perform all maintenance work. }\end{array}$ & 23.0 & $1,990.3$ \\
\hline \multicolumn{3}{|l|}{ Mutually Agreed Upon Workscope Deliverables and Due Dates } \\
\hline $\begin{array}{l}1 \text { Milestone 99-HFD-007, Fire Systems Preventive Maintenance Completion, due 9/30/99 } \\
2 \text { Milestone 99-HFD-008, Fire System Operability, due 9/30/99 }\end{array}$ & & \\
\hline Subtotal Net & 23.0 & $1,990.3$ \\
\hline Total Activity & 0.0 & $2,867.5$ \\
\hline Approved Net & 23.0 & $1,990.3$ \\
\hline Approved Total & 23.0 & $2,867.5$ \\
\hline
\end{tabular}




\section{FY 1999 Annual Work Plan}

\section{Part III - DOH/PMA/Service Center Rate Calculation Worksheet \\ (Dollars in 000's)}

Basis for Rate:

Cost components- Costs associated with the preventive maintenance of fire systems in most site facilities (excluding PNNL and part of the FFTF Reactor complex facilities) and repairs and modifications up to $\$ 5 \mathrm{k}$ per task. Repairs, installations, and modifications greater than $\$ 5 k$, and all removals are charged directly to the customer as direct labor and materials.

Cost distribution method- Costs are allocated to building owners based on the number and type of installed fire systems devices in each particular building. 


\begin{tabular}{|c|c|c|c|c|c|}
\hline \multicolumn{2}{|c|}{$\begin{array}{l}\text { Work Breakdown Structure and } \\
\text { Responsibility Assignment } \\
\text { Matrix }\end{array}$} & \multicolumn{2}{|c|}{$\begin{array}{c}\text { DynCorp Tri-Cities Services, Inc. } \\
\text { Hanford Fire Department } \\
\text { Program Plan } \\
\text { WBS } \quad 6.5 .7\end{array}$} & \multicolumn{2}{|c|}{$\begin{array}{c}\text { FY } 1999 \\
\text { Annual Work Plan }\end{array}$} \\
\hline $\begin{array}{l}\text { Program } \\
\text { Element }\end{array}$ & $\begin{array}{l}\text { Activity/Program } \\
\text { Sub-Element }\end{array}$ & Cost Account & Title & $\begin{array}{c}\text { Responsible } \\
\text { Manager }\end{array}$ & $\begin{array}{l}\text { Responsible } \\
\text { Organization }\end{array}$ \\
\hline \multirow[t]{3}{*}{6.5 .7} & 6.5 .7 .2 .2 & $1 \mathrm{~J} 5 \mathrm{E} 30$ & Hanford Fire Department & D. E. Good & $\begin{array}{l}\text { 5E300, Hanford Fire } \\
\text { Department }\end{array}$ \\
\hline & 6.5 .7 .4 .1 & $1 \mathrm{MDBOB}$ & $\begin{array}{l}\text { Life Safety, Property } \\
\text { Protection, and Fire } \\
\text { Systems Testing }\end{array}$ & D. E. Good & $\begin{array}{l}\text { 5E340, Hanford Fire } \\
\text { Department }\end{array}$ \\
\hline & 6.5 .7 .3 .3 & $1 \mathrm{MDCOF}$ & Fire Systems Maintenance & J. E. Finley & $\begin{array}{l}\text { 5E310, Fire } \\
\text { Protection Systems } \\
\text { Maintenance }\end{array}$ \\
\hline
\end{tabular}


0
0
0
0
0
0
0
0
0
$\frac{1}{3}$

0

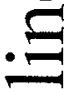

0

s

ธี

$m$

(1)

$\Xi$

0

J

U

$m$

$\frac{5}{0}$ 


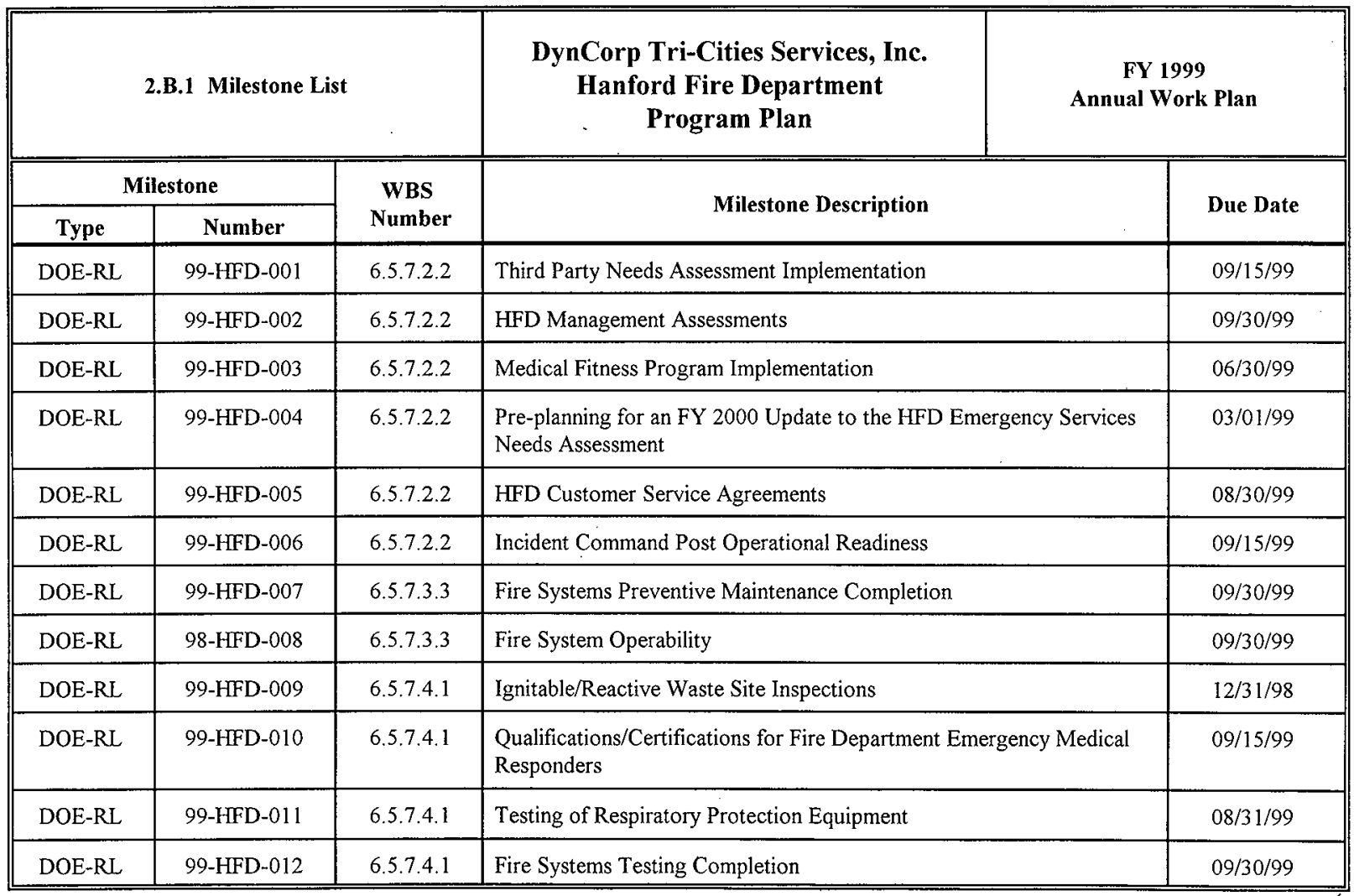




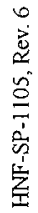

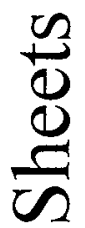

5

0

?

0

U

(1)



$\frac{1}{0}$

2 


\section{MULESTONE DESCRIPTION SHEET}

\begin{tabular}{|c|c|c|c|}
\hline \multicolumn{3}{|c|}{ Third Party Needs Assessment Implementation } & \multirow{2}{*}{$\begin{array}{l}\text { Date Prepared: } \\
\quad \text { October 1, } 1998 \\
\text { CIN: }\end{array}$} \\
\hline Assigned To: & Hanford Fire Dep & - D. E. Good & \\
\hline WBS Designator: & 6.5 .7 .2 .2 & & Due Date: $9 / 15 / 99$ \\
\hline Control Number: & 99-HFD-001 & & Revision: \\
\hline $\begin{array}{l}\text { Milestone Type: } \\
\square \text { DOE-HQ } \\
\square \text { DOE-RL } \\
\square \text { CNTR }\end{array}$ & $\begin{array}{l}\quad \text { Division: } \\
\square \text { State } \\
\square \text { Federal } \\
\text { } \text { DOE } \\
\square \text { RCRA } \\
\square \text { TPA\# }\end{array}$ & $\begin{aligned} & \text { Deliverable: } \\
& \text { Report } \\
& \text { Letter } \\
& \square \text { Drawings } \\
& \square \text { Other (specify) }\end{aligned}$ & $\begin{array}{l}\text { Address To: } \\
\square \text { DOE-HQ } \\
\square \text { DOE-RL } \\
\square \text { Other (specify) }\end{array}$ \\
\hline
\end{tabular}

\section{Milestone Description:}

Implement $100 \%$ of the third party needs assessment recommendations scheduled for completion in FY 1999.

\section{Description of what constitutes completion of this milestone:}

This milestone is closed when the needs assessment recommendations are implemented and reported in the monthly DOE-RL Contractor Monthly Fire Protection Report. 


\section{MUESTONE DESCRIPTION SHEET}

\begin{tabular}{|l|l|l|l|}
\hline \multicolumn{2}{|c|}{ Title: HFD Management Assessments } & $\begin{array}{l}\text { Date Prepared: } \\
\text { October 1, 1998 }\end{array}$ \\
\hline Assigned To: & \multicolumn{1}{|c|}{ Hanford Fire Department - D. E. Good } & CIN: \\
\hline WBS Designator: & 6.5 .7 .2 .2 & Due Date: 09/30/99 \\
\hline Control Number: & $99-$ HFD-002 & Revision: \\
\hline \multicolumn{1}{|c|}{ Milestone Type: } & \multicolumn{1}{|c|}{ Division: } \\
$\square$ DOE-HQ \\
$\begin{array}{l}\text { DOE-RL } \\
\text { CNTR }\end{array}$
\end{tabular}

\section{Milestone Description:}

Complete 100\% of the management assessments scheduled for completion in FY 1999.

\section{Description of what constitutes completion of this milestone:}

Completion of a minimum of 20 assessments and closure statements in the DOE-RL Contractor Monthly Fire Protection report. 


\section{MULESTONE DESCRIPTION SHEET}

\begin{tabular}{|c|c|c|c|}
\hline \multicolumn{3}{|c|}{ Medical Fitness Program Implementation } & $\begin{array}{l}\text { Date Prepared: } \\
\text { October } 1,1998\end{array}$ \\
\hline Assigned To: & Hanford Fire De & t - D. E. Good & CIN: \\
\hline WBS Designator: & 6.5 .7 .2 .2 & & Due Date: $06 / 30 / 99$ \\
\hline Control Number: & 99-HFD-003 & & Revision: \\
\hline $\begin{array}{l}\text { Milestone Type: } \\
\square \text { DOE-HQ } \\
\square \text { DOE-RL } \\
\square \text { CNTR }\end{array}$ & $\begin{array}{l}\quad \text { Division: } \\
\square \text { State } \\
\square \text { Federal } \\
\square \text { DOE } \\
\square \text { RCRA } \\
\square \text { TPA\# }\end{array}$ & $\begin{array}{l}\quad \text { Deliverable: } \\
\\
\text { neport } \\
\square \text { Letter } \\
\square \text { Drawings } \\
\square \text { Other (specify) }\end{array}$ & $\begin{array}{l}\text { Address To: } \\
\square \text { DOE-HQ } \\
\square \text { DOE-RL } \\
\square \text { Other (specify) }\end{array}$ \\
\hline
\end{tabular}

Milestone Description:

Implement a medical/fitness program for HFD emergency response personnel.

\section{Description of what constitutes completion of this milestone:}

This milestone is completed when a policy document is issued and implemented that establishes a medical/fitness program for HFD emergency response personnel, and the HFD's DOE-RL Monitor concurs with a letter closing this item. 


\section{MULSTONE DESCRIPTION SHEET}

\begin{tabular}{|c|c|c|c|}
\hline \multicolumn{3}{|c|}{$\begin{array}{l}\text { Pre-planning for an FY } 2000 \text { Update to the Hanford Fire } \\
\text { Department Emergency Services Needs Assessment }\end{array}$} & \multirow{2}{*}{$\begin{array}{l}\text { Date Prepared: } \\
\text { October 1, } 1998 \\
\text { CIN: }\end{array}$} \\
\hline Assigned To: & Hanford Fire Dep & -D. E. Good & \\
\hline WBS Designator: & 6.5 .7 .2 .2 & & Due Date: 03/01/99 \\
\hline Control Number: & 99-HFD-004 & & Revision: \\
\hline $\begin{aligned} & \text { Milestone Type: } \\
& \\
& \text { DOE-HQ } \\
& \text { DOE-RL } \\
& \text { CNTR }\end{aligned}$ & $\begin{array}{l}\quad \text { Division: } \\
\square \text { State } \\
\square \text { Federal } \\
\square \text { DOE } \\
\square \text { RCRA } \\
\square \text { TPA\# }\end{array}$ & $\begin{aligned} & \text { Deliverable: } \\
& \text { Report } \\
& \text { Retter } \\
& \square \text { Drawings } \\
& \square \text { Other (specify) }\end{aligned}$ & $\begin{array}{l}\quad \text { Address To: } \\
\square \text { DOE-HQ } \\
\square \text { DOE-RL } \\
\square \text { Other (specify) }\end{array}$ \\
\hline
\end{tabular}

\section{Milestone Description:}

Initiate actions to have an independent 3 rd party organization reevaluate near-term (5-7 years) emergency response requirements for the Hanford Site and update the April 1996 Hanford Site Emergency Response Needs Document.

\section{Description of what constitutes completion of this milestone:}

This milestone is complete when a draft Request for Proposal (RFP) has been submitted to RL for review. This RFP is to include estimated cost of the analysis to be performed, the estimated start and completion dates, and the estimated cost to be included in the DYN FY 2000 budget request. The RFP must require the performer to report review findings and to provide estimated costs, personnel resource requirements, and station or facility requirements. 


\section{MULESTONE DESCRIPTION SHEET}

\begin{tabular}{|c|c|c|c|}
\hline \multicolumn{3}{|c|}{ HFD Customer Service Agreements } & $\begin{array}{l}\text { Date Prepared: } \\
\text { October 1, } 1998\end{array}$ \\
\hline Assigned To: & \multicolumn{2}{|c|}{ Hanford Fire Department -W. R. Hayes } & CIN: \\
\hline WBS Designator: & \multicolumn{2}{|l|}{ 6.5.7.2.2 } & Due Date: $08 / 30 / 99$ \\
\hline Control Number: & \multicolumn{2}{|l|}{ 99-HFD-005 } & Revision: \\
\hline $\begin{aligned} & \text { Milestone Type: } \\
& \\
& \text { DOE-HQ } \\
& \text { DOE-RL } \\
& \text { CNTR }\end{aligned}$ & $\begin{array}{l}\quad \text { Division: } \\
\square \text { State } \\
\square \text { Federal } \\
\square \text { DOE } \\
\square \text { RCRA } \\
\square \text { TPA\# } \\
\end{array}$ & $\begin{aligned} & \text { Deliverable: } \\
& \\
& \text { Report } \\
& \text { 1 Letter } \\
& \square \text { Drawings } \\
& \square \text { Other (specify) }\end{aligned}$ & $\begin{aligned} & \text { Address To: } \\
\square & \text { DOE-HQ } \\
& \text { DOE-RL } \\
& \text { Other (specify) }\end{aligned}$ \\
\hline \multicolumn{4}{|c|}{ Milestone Description: } \\
\hline \multicolumn{4}{|c|}{ Complete customer service agreements with all site customers of HFD Fire Systems Testing services } \\
\hline \multicolumn{4}{|c|}{ Description of what constitutes completion of this milestone: } \\
\hline
\end{tabular}




\section{MULESTONE DESCRIPTION SHEET}

\begin{tabular}{|c|c|c|c|}
\hline \multicolumn{3}{|c|}{ Incident Command Post Operational Readiness } & $\begin{array}{l}\text { Date Prepared: } \\
\text { October 1, } 1998\end{array}$ \\
\hline Assigned To: & \multicolumn{2}{|c|}{ Hanford Fire Department - D. E. Good } & CIN: \\
\hline WBS Designator: & \multicolumn{2}{|l|}{6.5 .7 .2 .2} & Due Date: 09/15/99 \\
\hline Control Number: & \multicolumn{2}{|l|}{ 98-HFD-006 } & Revision: \\
\hline $\begin{array}{l}\text { Milestone Type: } \\
\square \text { DOE-HQ } \\
\square \text { DOE-RL } \\
\square \text { CNTR }\end{array}$ & $\begin{array}{l}\quad \text { Division: } \\
\square \text { State } \\
\square \text { Federal } \\
\text { Q DOE } \\
\square \text { RCRA } \\
\square \text { TPA\# }\end{array}$ & $\begin{array}{l}\quad \text { Deliverable: } \\
\text { n Report } \\
\square \text { Letter } \\
\square \text { Drawings } \\
\square \text { Other (specify) }\end{array}$ & $\begin{aligned} & \text { Address To: } \\
& \\
& \square \text { DOE-HQ } \\
& \text { DOE-RL } \\
& \square \text { Other (specify) }\end{aligned}$ \\
\hline \multicolumn{4}{|c|}{$\begin{array}{l}\text { Develop training curriculum and establish an annual site-wide Incident Command Post training program } \\
\text { Elements will include an implementation plan to place the new mobile command unit in service and a } \\
\text { training schedulethat includes an operational drill at each of the } 24 \text { hazardous facilities. }\end{array}$} \\
\hline \multicolumn{4}{|c|}{$\begin{array}{l}\text { This milestone is completed when: } \\
\text { - The mobile incident command post is placed in service } \\
\text { - The curriculum for command post usage during drills and emergent events is completed } \\
\text { - Training drills have been scheduled and conducted at each of the } 24 \text { hazardous facilities }\end{array}$} \\
\hline
\end{tabular}




\section{MULESTONE DESCRIPTION SHEET}

\begin{tabular}{|c|c|c|c|}
\hline \multicolumn{3}{|c|}{ Fire Systems Preventive Maintenance Completion } & Date Prepared: \\
\hline Assigned To: & Hanford Fire Departn & Finiey & CIN: \\
\hline WBS Designator: & 6.5.7.3.3 & & Due Date: 09/30/99 \\
\hline Control Number: & 99-HFD-007 & & Revision: \\
\hline $\begin{array}{l}\text { Milestone Type: } \\
\square \text { DOE-HQ } \\
\square \text { DOE-RL } \\
\square \text { CNTR }\end{array}$ & $\begin{array}{l}\quad \text { Division: } \\
\square \text { State } \\
\square \text { Federal } \\
\square \text { DOE } \\
\square \text { RCRA } \\
\square \text { TPA\# }\end{array}$ & $\begin{aligned} & \text { Deliverable: } \\
& \\
& \text { Report } \\
& \square \text { Letter } \\
& \square \text { Drawings } \\
& \square \text { Other (specify) }\end{aligned}$ & $\begin{aligned} & \text { Address To: } \\
& \\
\square & \text { DOE-HQ } \\
& \text { DOE-RL } \\
\square & \text { Other (specify) }\end{aligned}$ \\
\hline
\end{tabular}

\section{Milestone Description:}

Complete $100 \%$ of the fire protection system preventive maintenance scheduled for performance by HFD personnel for the year.

\section{Description of what constitutes completion of this milestone:}

Completion of 100 percent of scheduled preventive maintenance as measured in the statistics provided to $\mathrm{RL}$ in the fire department monthly operations report. PMs that cannot be completed due to circumstances beyond the control of the HFD will not be included in this milestone. 


\section{MULESTONE DESCRIPTION SHEET}

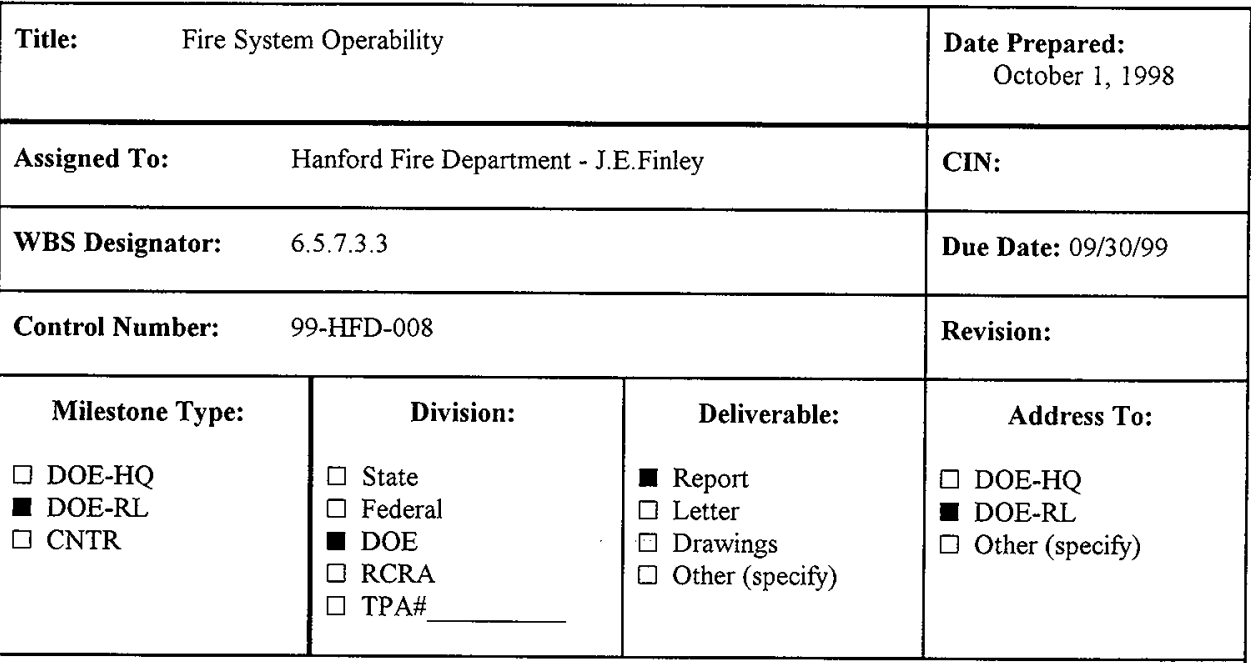

\section{Milestone Description:}

Maintain an average fire system operability rate of $98 \%$ or higher over the course of the year.

\section{Description of what constitutes completion of this milestone:}

Milestone is completed when FY 1999 total fire system operability, as reported in the DOE-RL Fire Protection monthly report for September 1999 averages $98 \%$ or higher for the previous 12 months. 


\section{MILESTONE DESCRUTION SHEET}

Title: $\quad$ Ignitable/Reactive Waste Site Inspections in FY 1998

Date Prepared:

October 1, 1998

\begin{tabular}{|c|c|c|c|}
\hline Assigned To: & \multicolumn{2}{|c|}{ Hanford Fire Department - R. E. Jordan } & CIN: \\
\hline WBS Designator: & \multicolumn{2}{|l|}{6.5 .7 .4 .1} & Due Date: $12 / 31 / 98$ \\
\hline Control Number: & \multicolumn{2}{|l|}{ 99-HFD-009 } & Revision: \\
\hline $\begin{array}{l}\text { Milestone Type: } \\
\square \text { DOE-HQ } \\
\square \text { DOE-RL } \\
\square \text { CNTR }\end{array}$ & $\begin{aligned} & \text { Division: } \\
& \square \text { State } \\
\square & \text { Federal } \\
& \text { DOE } \\
\square & \text { RCRA } \\
& \text { TPA\# }\end{aligned}$ & $\begin{array}{l}\quad \text { Deliverable: } \\
\text { n Report } \\
\square \text { Letter } \\
\square \text { Drawings } \\
\square \text { Other (specify) }\end{array}$ & $\begin{aligned} & \text { Address To: } \\
& \square \text { DOE-HQ } \\
& \text { DOE-RL } \\
& \square \text { Other (specify) }\end{aligned}$ \\
\hline
\end{tabular}

\section{Milestone Description:}

Complete $100 \%$ of the required ignitable and reactive waste storage site inspections due in FY 1999

Description of what constitutes completion of this milestone:

Completion of inspections and reporting of this completion in the DOE-RL Monthly Fire Protection Report. 


\section{MrLeSTONE DESCRIPTION SHEET}

\begin{tabular}{|c|c|c|c|}
\hline \multicolumn{3}{|c|}{$\begin{array}{l}\text { Qualifications/Certifications for Fire Department Emergency } \\
\text { Medical Responders }\end{array}$} & \multirow{2}{*}{$\begin{array}{l}\text { Date Prepared: } \\
\text { October 1, } 1998 \\
\text { CIN: }\end{array}$} \\
\hline Assigned To: & Hanford Fire Departn & M. Knight & \\
\hline WBS Designator: & 6.5 .7 .4 .1 & & Due Date: 09/15/99 \\
\hline Control Number: & 99-HFD-010 & & Revision: \\
\hline $\begin{array}{l}\text { Milestone Type: } \\
\square \text { DOE-HQ } \\
\square \text { DOE-RL } \\
\square \text { CNTR }\end{array}$ & $\begin{array}{l}\quad \text { Division: } \\
\quad \square \text { State } \\
\square \text { Federal } \\
\text { DOE } \\
\square \text { RCRA } \\
\square \text { TPA\# }\end{array}$ & $\begin{aligned} & \text { Deliverable: } \\
& \text { Report } \\
& \square \text { Letter } \\
& \square \text { Drawings } \\
& \square \text { Other (specify) }\end{aligned}$ & $\begin{array}{l}\quad \text { Address To: } \\
\square \text { DOE-HQ } \\
\square \text { DOE-RL } \\
\square \text { Other (specify) }\end{array}$ \\
\hline
\end{tabular}

\section{Milestone Description:}

Maintain $100 \%$ of the qualifications and certifications necessary for paramedics and emergency medical technicians to provide site emergency medical response services.

Description of what constitutes completion of this milestone:

Maintenance of $100 \%$ of the required emergency medical training as reported in the HFD training database. 


\section{MULESTONE DESCRIPTION SHEET}

\begin{tabular}{|c|c|c|c|}
\hline \multicolumn{3}{|c|}{ Testing of Respiratory Protection Equipment } & Date Prepared: \\
\hline Assigned To: & Hanford Fire Departs & R. Hayes & CIN: \\
\hline WBS Designator: & 6.5 .7 .4 .1 & & Due Date: 08/31/99 \\
\hline Control Number: & 99-HFD-011 & & Revision: \\
\hline $\begin{array}{l}\text { Milestone Type: } \\
\square \text { DOE-HQ } \\
\text { DOE-RL } \\
\square \text { CNTR }\end{array}$ & $\begin{array}{l}\quad \text { Division: } \\
\square \text { State } \\
\square \text { Federal } \\
\text { } \text { DOE } \\
\square \text { RCRA } \\
\square \text { TPA\# }\end{array}$ & $\begin{array}{l}\quad \text { Deliverable: } \\
\\
\text { - Report } \\
\square \text { Letter } \\
\square \text { Drawings } \\
\square \text { Other (specify) }\end{array}$ & $\begin{aligned} & \text { Address To: } \\
\square & \text { DOE-HQ } \\
& \text { DOE-RL } \\
\square & \text { Other (specify) }\end{aligned}$ \\
\hline
\end{tabular}

\section{Milestone Description:}

Complete $100 \%$ of the code-required testing of HFD respiratory protection equipment scheduled for FY 1999.

\section{Description of what constitutes completion of this milestone:}

Completion of $100 \%$ of the scheduled testing and reporting this in the DOE-RL Monthly Fire Protection Report. 
MILESTONE DESCRIPTION SHEET

\begin{tabular}{|c|c|c|c|}
\hline \multicolumn{3}{|c|}{ Title: $\quad$ Fire Systems Testing Completion } & $\begin{array}{l}\text { Date Prepared: } \\
\text { October 1.1998 }\end{array}$ \\
\hline Assigned To: & \multicolumn{2}{|c|}{ Hanford Fire Department - W. R. Hayes } & CIN: \\
\hline WBS Designator: & \multicolumn{2}{|l|}{6.5 .7 .4 .1} & Due Date: 09/30/99 \\
\hline Control Number: & \multicolumn{2}{|l|}{ 99-HFD-012 } & Revision: \\
\hline Milestone Type: & Division: & Deliverable: & Address To: \\
\hline $\begin{array}{l}\square \text { DOE-HQ } \\
\text { DOE-RL } \\
\square \text { CNTR }\end{array}$ & $\begin{array}{l}\square \text { State } \\
\square \text { Federal } \\
\square \text { DOE } \\
\square \text { RCRA } \\
\square \text { TPA\# }\end{array}$ & $\begin{array}{l}\text { Report } \\
\square \text { Letter } \\
\square \text { Drawings } \\
\square \text { Other (specify) }\end{array}$ & $\begin{array}{l}\square \text { DOE-HQ } \\
\square \text { DOE-RL } \\
\square \text { Other (specify) }\end{array}$ \\
\hline
\end{tabular}

\section{Milestone Description:}

Complete 100 percent of the functional fire protection system testing scheduled for performance by HFD personnel for the year.

\section{Description of what constitutes completion of this milestone:}

Completion of 100 percent of fire systems testing as measured in the statistics provided to RL in the fire department monthly operations report. Testing that cannot be completed due to circumstances beyond the control of the HFD will not be included in this milestone. 